\title{
Optimization of the design of polygeneration systems for the residential sector under different self-consumption regulations.
}

\author{
Edwin S. Pinto, Luis M. Serra, Ana Lázaro \\ GITSE I3A, Department of mechanical engineering, University of Zaragoza, Spain
}

\begin{abstract}
Polygeneration systems enable natural resources to be exploited efficiently, decreasing $\mathrm{CO}_{2}$ emissions and achieving economic savings relative to the conventional separate production. However, their economic feasibility depends on the legal framework. Preliminary design of polygeneration systems for the residential sector based on the last Spanish self-consumption regulations RD 900/2015 and RD 244/2019 was carried out in Zaragoza-Spain. Both regulations were applied to individual and collective installations. Several technologies, appropriate for the energy supply to residential buildings, e.g. photovoltaics, wind turbines, solar thermal collectors, microcogeneration engines, heat pump, gas boiler, absorption chiller and thermal and electric energy storage were considered candidate technologies for the polygeneration system. A Mixed Integer Linear Programming model was developed to minimize the total annual cost of polygeneration systems. Scenarios with and without electricity sale were considered. $\mathrm{CO}_{2}$ emissions were also calculated to estimate the environmental impact. Results show that RD 900/2015 discourages the investment in self-consumption systems whereas the RD 244/2019 encourages them, especially in renewable energy technologies. Moreover, in economic terms, it is more profitable to invest in collective self-consumption installations over individual installations. However, this does not necessarily represent a significant reduction of $\mathrm{CO}_{2}$ emissions with respect to individual installations since the natural gas consumption tends to increase as its unit price decreases because of the increase of its consumption level. Thus, more appropriate pricing of natural gas in residential sector, in which its cost would not be reduced when increasing its consumption, would be required to achieve significant $\mathrm{CO}_{2}$ emissions reduction. In all cases, the PV panels are competitive and profitable without subsidies in self-consumption schemes and the reversible heat pumps played an important role for the $\mathrm{CO}_{2}$ emissions reduction. In a horizon to achieve cero $\mathrm{CO}_{2}$ emissions, the net metering scheme could be an interesting and profitable alternative to be considered.
\end{abstract}

Keywords: Self-consumption regulations, Renewable energy, Polygeneration systems optimization, energy supply systems for buildings

\section{Introduction}

The residential sector represents about $27 \%$ of the energy consumption and $17 \%$ of the $\mathrm{CO}_{2}$ emissions of the world. Therefore, this sector plays an important role in the policies to mitigate climate change and its impacts [1]. Accordingly, it is one of the objective sectors in the pathway to limit global warming to $1.5^{\circ} \mathrm{C}$ according to the last report of the Intergovernmental Panel on Climate Change (IPCC) [2]. 
Design of buildings with low energy consumption has been, during the last two decades, a matter of research and study [3,4]. There are approaches oriented to reduce the building's energy demand, through the design of buildings with very low energy requirements [5], and also through the implementation of efficient energy supply systems considering as well the integration of renewable energy technologies [6,7].

The integration of thermal and electrical systems makes feasible to increase the share of renewable energy and also achieving $\mathrm{CO}_{2}$ emissions reduction [4]. In this sense, polygeneration systems for residential buildings can be a suitable alternative to reduce economic costs and $\mathrm{CO}_{2}$ emissions with respect to the separate production of energy services, thanks to an adequate systems integration [8].Therefore, distributed generation (based on polygeneration systems) is considered an alternative to increase the share of renewable energy in energy mix of countries, reducing the environmental impact of the energy generation infrastructure and improving its sustainability $[9,10]$.

Polygeneration in residential buildings generally refers to the combined production of electricity, heat and cooling [11,12]. They consist of different energy technologies, which convert renewable and non-renewable energy resources into the energy services required in the building along the day and the year. Internal combustion engines, gas turbines, micro-turbines or fuel cells may act as prime movers, coupled to an electric generator when required, in which the chemical energy of fossil fuels or biomass is converted into electrical power. The heat released can be used for the production of domestic hot water (DHW) and/or space heating. Further, thanks to the integration of thermally activated technologies such as absorption chillers, cooling production for air conditioning can also be obtained using the available excess of heat produced in periods in which heating space is not required. Mechanical chillers allow also the cooling production thanks to the efficient conversion of electrical energy. In this respect, reversible heat pumps, producing alternatively both, heating or cooling, are also interesting candidate technologies of polygeneration systems in residential buildings that, together with auxiliary boilers, may complement and avoid the oversizing of the prime mover [13]. Technologies driven by renewable energies (e.g. photovoltaic panels, solar thermal collectors, hybrid photovoltaic/thermal, wind turbines, among others) providing higher flexibility and diversification as well as environmental benefits, also play a key role in the design of sustainable energy supply systems for residential buildings [14-16]. They can cover multiple energy demands directly (e.g. electricity from photovoltaic or wind turbines, or heat from solar thermal collectors) or indirectly by coupling absorption and/or mechanical heat pumps $[17,18]$. Nevertheless, non-manageable energy technologies, such as wind or solar energy, are not able of covering alone in a reasonable and competitive way the full demand of energy services of buildings. In this respect the combination of nonmanageable renewable energy sources with manageable energy sources (e.g. conventional fossil fuels) and with the integration of energy storage (e.g. electric batteries, thermal energy storage -hot water tanks for heating or chilled water for cooling) allow to reach a significant fraction of renewable energy, to increase the energy security, to reduce the installed capacity of some technologies, to increase the environmental benefits and to reduce the operation costs $[19,20]$. Another important aspect to be considered in the design of affordable polygeneration systems for residential buildings is the connection with the electrical grid and the possibility of purchasing and/or selling electricity to it, 
which provides reliability and security to the building energy supply as well as flexibility and economic benefits [21,22].

However, the feasibility of polygeneration systems depends, among others, on the applied energy policies and legal framework. For instance, previous studies have demonstrated how some policies could promote or limit the installation of specific technologies such as cogeneration [23] or photovoltaic technology [24].

In order to encourage a deployment of energy efficient and low carbon grid connected distributed generation, several targets and policies have been proposed by the governments around the world. In particular, regulatory and pricing policies such as feedin tariffs (FiT), net metering or net billing have been applied to support distributed generation DG [25]. A brief description of those pricing policies schemes are presented in the following paragraphs.

Feed-in Tariff (FiT): In this scheme, electricity consumption and generation must be separated and accounted differently. While electricity from the grid is purchased at retail price, the electricity injected to the grid is compensated at a predetermined tariff notified by the regulator which can be higher than retail electricity price [26]. When the compensation tariff is indeed higher than the retail electricity price, this scheme can be called Buy all, Sell All arrangement [27].

Net metering or Net energy metering: Under this mechanism, the electricity bill for the net electricity consumption from the grid is accounted after netting off the electricity injected by the owner into the grid. This requires bidirectional meters, or net meters, which keep account of the net flow of electricity. In this case, the owner receives a credit in kilowatt-hours and typically is compensated for the injected electricity at the retail electricity tariff [26].

Net billing: In this scheme, the compensation is monetary. The owner can consume electricity generated by renewable energy installation in real-time and export any surplus generation to the utility grid. All net electricity exports are metered and credited at a predetermined sell rate in the moment they are injected into the grid. The sell rate is lower to the retail rate of electricity [27].

Several countries, such as Germany or Canada, have applied FiT mechanisms to encourage the renewable technology investment as Buy All, Sell All arrangement. However, this mechanism has evolved to net billing arrangements as self-consumption (and offer lower rates for exported energy) [27,28].

In the case of Spain, in particular, in the last four years, the Spanish government has implemented two different royal decrees to regulate the self-consumption.

The first of them is the Royal Decree RD 900/2015 [29] which was appropriated in 2015 and defined two types of self-consumption systems: i) Self-consumption type 1: For systems with installed polygeneration system capacity below $100 \mathrm{~kW}$ in which energy sale is not allowed and ii) Self-consumption type 2: there was no limit for installed polygeneration system capacity (either lower or upper limit) and energy sale was allowed. The self-consumption type 2 can be considered as a net billing arrangement. In both types, the installed polygeneration system capacity must be lower than or equal to the contracted 
capacity from the grid. A relevant aspect of this regulation is that it must be applied two types of self-consumption taxes: i) a fix tax proportional to the difference between the charges application power and the contracted power from the grid, in this work this fix tax is applied to the installed polygeneration system capacity; and ii) a variable tax corresponding to the self-consumed energy, depending on time-of-use tariffs. However, for self-consumption type 1 when contracted power from the grid is lower or equal to 10 $\mathrm{kW}$, self-consumption taxes were not applied.

Recently, the Spanish government has released the Royal Decree RD 244/2019 [30] which stablishes the administrative, technical and economic conditions for selfconsumption. This decree derogates the previous one, RD 900/2015, and settles down two categories of self-consumption: i) self-consumption without surplus electricity production, in which electricity injection to the grid is not allowed, and ii) selfconsumption with surplus, in which electricity injection to the grid is allowed. Both selfconsumption categories can be applied for individual or collective installations. The selfconsumption with surplus type is divided in two types: a) Surplus subject to compensation: In this case, the primary energy must be renewable and the installed polygeneration system capacity must be equal or lower than $100 \mathrm{~kW}$, and b) Surplus no subject to compensation: Self-consumption systems that do not accomplish the requirements to be subjected to compensation or that voluntarily decide do not receive any economic compensation. This could happen, because when a client wants to sell electricity to the grid, some additional administrative and technical requirements should be fulfilled, which also could require to pay additional fees Then, if the surplus of electricity is a small amount, it could be more interesting to avoid these technical and administrative issues. Besides, in this way, he/she can deliver surplus electricity to the grid, with more flexibility of operation and avoiding the additional investment in any dissipater or battery required to manage the excess of electricity produced.

A relevant difference between both regulations is that in the Royal Decree 244/2019 there is neither application of any tax related to self-consumption nor any restriction on the installed self-consumption system capacity with respect to the contracted power from the electric grid. However, in the case of surplus subject to compensation, i.e. produced with renewable energy, the installed capacity must be equal or lower than $100 \mathrm{~kW}$.

This work aims to compare both regulations by evaluating their impacts on the design of polygeneration systems for the residential sector from the economic and environmental points of view. Although collective installations are not mentioned in the RD 900/2015, in this work both individual and collective installations are studied for both regulations, by considering households as a reference for individual installations, and residential buildings as a reference for collective installations. Three scenarios based on the abovementioned regulations are considered: i) Scenario 1: Electricity sale is not allowed; ii) Scenario 2: Electricity sale is allowed at spot price; iii) Scenario 3: Electricity sale is allowed at 80\% purchase price. In addition, Spanish regulation RD 244/2019 establishes that the surplus electricity cannot be greater than the consumed electricity from the grid in economic terms for the billing time, which cannot exceed 1 month [30]; however, in this work due to the procedure applied to select representative days in the optimization model, the considered billing time is one year. This approach is less restrictive and provides higher flexibility to self-consumption arrangements. 
Scenarios 2 and 3 are proposed as particular examples of the type 2 self-consumption in both regulations $[29,30]$, and they are, in fact, net billing arrangements under legal restrictions based on the regulations.

Table 1 summarizes the legal restrictions considered for the design of polygeneration systems in this work which are mainly based on the aforementioned royal decrees.

Table 1. Legal restrictions considered in this work for the design of polygeneration systems

\begin{tabular}{|c|c|c|c|c|}
\hline \multirow{2}{*}{ Feature } & \multicolumn{2}{|c|}{ Based on RD 900/2015 } & \multicolumn{2}{|c|}{ Based on RD 244/2019 } \\
\hline & Individual & Collective & Individual & Collective \\
\hline $\begin{array}{l}\text { Polygeneration } \\
\text { system size }\end{array}$ & \multicolumn{2}{|c|}{ Below or equal to contracted grid power } & \multicolumn{2}{|c|}{ Unlimited } \\
\hline $\begin{array}{l}\text { Mechanism of } \\
\text { compensation }\end{array}$ & \multicolumn{2}{|c|}{ Net billing (optional) } & \multicolumn{2}{|c|}{ Net billing (optional) } \\
\hline Sale electricity & \multicolumn{2}{|c|}{ Surplus electricity (optional) } & \multicolumn{2}{|c|}{$\begin{array}{l}\text { Surplus electricity only from } \\
\text { renewable resources (Optional) }\end{array}$} \\
\hline $\begin{array}{l}\text { Charges over } \\
\text { self- } \\
\text { consumption }\end{array}$ & $\begin{array}{l}\text { When contracted power is above } \\
10 \mathrm{~kW} \text { or sale electricity is applied }\end{array}$ & Yes & \multicolumn{2}{|c|}{ No } \\
\hline
\end{tabular}

Mixed Integer Linear Programming is utilized for the design of the polygeneration systems by applying the superstructure optimization methodology. The feasibility of several candidate technologies are evaluated for the optimal design [31]. The optimization was carried out with the objective to minimize the total annual cost, and $\mathrm{CO}_{2}$ emissions were also calculated in order to estimate the environmental impact of the system. In this way, the greenhouse gas emissions reduction was verified, which is one of the aims of the new self-consumption policy [32].

The analyses presented in this work provide valuable information for the comparison of the different policies, previously referred, that have been proposed by the governments around the world to support distributed generation DG, such as feed-in tariffs (FiT), net metering or net billing [25].

\section{Methodology}

\subsection{Description of the system}

The location of this study is in Zaragoza, Spain (latitude $41.7^{\circ}$ ). Two cases have been considered for this work:

- Household (Hh): A single dwelling (which belongs to a residential building) occupied by 3 people with a surface area of $102.4 \mathrm{~m}^{2}$. The expected contracted power is below $10 \mathrm{~kW}$; therefore, the electric tariff 2.0 DHS is applied [33]. The available surface area for photovoltaic panels or solar thermal collectors is $100 \mathrm{~m}^{2}$.

- Residential building (RB): It consists of a multifamily residential building composed of 50 dwellings (households), each one with $102.4 \mathrm{~m}^{2}$ of surface area and average occupancy of 3 people per dwelling. The community can sign-up a collective selfconsumption contract for all services. The expected electricity contracted power is above $15 \mathrm{~kW}$; therefore, the electric tariff 3.0A is applied in this case [33]. The available area for photovoltaic panels or solar thermal collectors is $2000 \mathrm{~m}^{2}$. 


\subsubsection{Energy demands}

Energy demands were calculated from annual data. Space heating $S H_{d}$ and cooling $R_{d}$ demands per dwelling are about 41 and $11 \mathrm{kWh} /\left(\mathrm{m}^{2} \cdot \mathrm{yr}\right)$ respectively [34]. The electricity demand for appliances is about $28.7 \mathrm{kWh} /\left(\mathrm{m}^{2} \cdot \mathrm{yr}\right)$ [35]. The domestic hot water (DHW) average consumption is about $28 \mathrm{~L} /($ person·day) [36]. The procedure to obtain hourly data is described as follows:

For space heating and cooling demands, the degree days method was applied for distributing the annual energy demand throughout all the days of the year. The considered base temperatures for heating and cooling were $15{ }^{\circ} \mathrm{C}$ and $21{ }^{\circ} \mathrm{C}$, respectively [37], and the ambient temperature was obtained from the meteonorm database [38]. A hourly function [39] was applied on daily data to obtain hourly space heating and cooling demands.

The domestic hot water volume was monthly distributed by applying a distribution factor [40]. The energy required to heat the monthly volume of water was calculated considering the water network supply temperature [41] and the DHW set temperature of $60{ }^{\circ} \mathrm{C}$ according to the Spanish regulation [36]. Monthly energy was divided by days of the month and distributed by means of an hourly distribution function [39]. This procedure assumes that the hourly DHW energy demand $Q_{D H W}$ is the same for each day of the month.

The annual electricity demand for appliances and lighting was monthly distributed by applying a distribution factor. Then, the monthly values were divided by the days of the month and distributed by an hourly distribution function [42]. In this way the hourly electricity demand $E_{d}$ was obtained.

The procedures briefly described above, provide the hourly demand data series of heating $Q_{d}$, cooling $R_{d}$ and electricity $E_{d}$. Heating demand consists of domestic hot water $Q_{D H W}$ and space heating $S H_{d}$, considering a low temperature radiant heating indoor end system, with operation temperatures about of $45{ }^{\circ} \mathrm{C}$, with the possibility to reach temperatures about $60{ }^{\circ} \mathrm{C}$ for $\mathrm{DHW}$. Therefore, temperature levels of both demands are quite the same.

\subsubsection{Renewable energy production}

Hourly photovoltaic energy production per square meter, $E_{P V}$, was calculated following the procedure described by Duffie and Beckman [43], as a function of solar radiation on the surface tilted at $36^{\circ}$ and azimuth angle $0^{\circ}$ [38]. The PV panels are polycrystalline technology of $255 \mathrm{Wp}$ with a maximum point power efficiency $\eta_{m p, r e f}=15.66 \%$ and an open-circuit voltage temperature coefficient $\mu$ voc $=-0.32 \% /{ }^{\circ} \mathrm{C}[44]$.

Hourly solar thermal energy production per square meter, $E_{S T}$, was calculated as a function of solar radiation on surface tilted at $36^{\circ}$ and azimuth angle $0^{\circ}$, and the mean temperature difference between the collector temperature $60^{\circ} \mathrm{C}$ and ambient temperature. The collector parameters are optical efficiency $\eta_{o}=80.1 \%$ and $1^{\text {st }}$ and $2^{\text {nd }}$ order heat loss coefficients $a_{1}=3.188 \mathrm{~W} /\left(\mathrm{m}^{2} \cdot \mathrm{K}\right), a_{2}=0.011 \mathrm{~W} /\left(\mathrm{m}^{2} \cdot \mathrm{K}^{2}\right)$ [45].

Restrictions due to shading were considered taking into account both PV panels and solar thermal collectors area [46]. The relation between the required horizontal surface area 
and the installed area was about 2.5:1 for PV panels and 5:1 for Solar thermal collectors.

The electrical production of the wind turbine, $E_{W}$, depends on the wind speed [38] and was calculated based on the production curve of a wind turbine with nominal capacity of $3 \mathrm{~kW}$ [47] for small scale (Hh) and $30 \mathrm{~kW}$ [48] for medium scale (RB), following the procedure described by Manwell et al. [49].

A summary of annual and peak values of energy demands and renewable energy production is presented in Table 2 . The peak demands correspond to the maximum value of each hourly time series.

Table 2. Summary of annual and peak values of energy demands and renewable energy production for households and residential buildings.

\begin{tabular}{|c|c|c|c|c|c|c|c|c|}
\hline \multirow{3}{*}{$\begin{array}{l}\text { Attributes } \\
\text { Energy demands } \\
\text { Heating demand }\left(\mathrm{Q}_{\mathrm{d}}\right)\end{array}$} & \multicolumn{4}{|c|}{ Household } & \multicolumn{4}{|c|}{ Residential building (50 dwellings) } \\
\hline & \multicolumn{2}{|c|}{ Annual Value } & \multicolumn{2}{|c|}{ Peak Value } & \multicolumn{2}{|c|}{ Annual Value } & \multicolumn{2}{|c|}{ Peak Value } \\
\hline & 5832 & kWht & 5.5 & $\mathrm{kWt}$ & 291607 & kWht & 274 & $\mathrm{kWt}$ \\
\hline Cooling demand $\left(\mathrm{R}_{\mathrm{d}}\right)$ & 1167 & kWht & 5.9 & $\mathrm{kWt}$ & 58368 & kWht & 293 & $\mathrm{kWt}$ \\
\hline Electricity demand $\left(E_{d}\right)$ & 2939 & $\mathrm{kWh}$ & 0.6 & $\mathrm{~kW}$ & 146950 & $\mathrm{kWh}$ & 30 & $\mathrm{~kW}$ \\
\hline Renewable energy production & \multicolumn{2}{|c|}{ Annual Value } & \multicolumn{2}{|c|}{ Peak Value } & \multicolumn{2}{|c|}{ Annual Value } & \multicolumn{2}{|c|}{ Peak Value } \\
\hline Photovoltaic production (Epv) & 285 & $\mathrm{kWh} / \mathrm{m}^{2}$ & 0.16 & $\mathrm{~kW} / \mathrm{m}^{2}$ & 285 & $\mathrm{kWh} / \mathrm{m}^{2}$ & 0.16 & $\mathrm{~kW} / \mathrm{m}^{2}$ \\
\hline Wind energy $(\mathrm{Ew})$ & 6397 & kWh/ud & 3.4 & $\mathrm{~kW} / \mathrm{ud}$ & 53991 & kWh/ud & 39 & $\mathrm{~kW} / \mathrm{ud}$ \\
\hline Solar Thermal Production (Est) & 995 & $\mathrm{kWht} / \mathrm{m}^{2}$ & 0.79 & $\mathrm{kWt} / \mathrm{m}^{2}$ & 995 & $\mathrm{kWht} / \mathrm{m}^{2}$ & 0.79 & $\mathrm{kWt} / \mathrm{m}^{2}$ \\
\hline
\end{tabular}

\subsubsection{Input data from the grid}

Hourly electricity spot prices [50] were required for the system in order to calculate the revenues for selling surplus electricity to the grid. Moreover, hourly $\mathrm{CO}_{2}$ emissions from the grid [51] were considered in order to evaluate the environmental impact of the systems.

\subsection{Representative days}

The optimization of polygeneration systems considering the entire year data when several time series and binary variables are involved in the model is a computational demanding task. Representative days have been widely used in several works to tackle this issue [5254]. Taking into account that this work considered time series with high variability, such as wind energy production and hourly electricity spot prices, herein, the $k \mathrm{M}$-OPT method [55] was applied in order to select 12 representative days for the optimization of polygeneration systems. This method combines two methods, the $k$-Medoids [56] which aims to group the days of the year into clusters so that the cluster members are as similar as possible, and the OPT method [53] which consists of fitting the data duration curve obtained from representative periods to the duration curve of the original time series. By combining both of them, it is possible to reduce the smoothing of typical periods improving the optimization results of the polygeneration systems. One of the drawbacks of this method lies in the non-consecutive order of the selected days, which makes it difficult to carry out monthly analysis in terms of economic billings, therefore, yearly analysis was carried out. Tables 3 and 4 show the set of representative days with their respective weights $\omega$ (which corresponds to the multiplication factor of each 
representative day). Two additional days corresponding to cooling and heating peak demands were considered with weight zero, which have influence on the sizing of the equipment but not on the operational cost. Time series considered for households and residential buildings have the same dynamic behaviour, except for the electrical production of the wind turbine. This leads to two different sets of representative days.

Table 3. Set of representative days for household system

\begin{tabular}{|c|c|c||c|c|c||c|c|c|}
\hline Month & Day (d) & Weight $(\boldsymbol{\omega})$ & Month & Day (d) & weight $(\boldsymbol{\omega})$ & Month & Day (d) & weight $(\boldsymbol{\omega})$ \\
\hline January & 19 & 16 & May & 127 & 36 & July & 208 & 23 \\
\hline March & 62 & 29 & June & 177 & 43 & November & 326 & 22 \\
\hline April & 112 & 34 & July & 206 & 22 & December & 339 & 37 \\
\hline April & 116 & 27 & July & 207 & 46 & December & 343 & 30 \\
\hline
\end{tabular}

Table 4. Set of representative days for residential building system

\begin{tabular}{|c|c|c||c|c|c||c|c|c|}
\hline Month & Day $(\boldsymbol{d})$ & Weight $(\boldsymbol{\omega})$ & Month & Day $(\boldsymbol{d})$ & weight $(\boldsymbol{\omega})$ & Month & Day $(\boldsymbol{d})$ & weight $(\boldsymbol{\omega})$ \\
\hline February & 37 & 40 & June & 162 & 39 & August & 235 & 42 \\
\hline March & 62 & 30 & June & 177 & 39 & October & 298 & 31 \\
\hline April & 112 & 40 & July & 208 & 23 & December & 339 & 38 \\
\hline April & 116 & 22 & August & 221 & 10 & December & 352 & 11 \\
\hline
\end{tabular}

\subsection{Superstructure}

The superstructure depicted in the figure 1 considers the candidate technologies and the feasible connections between them. The system is composed of an electrical and a thermal part. The electrical part consists of the electric grid from which an specific power can be contracted according to the tariff; photovoltaic modules PV whose electrical production $W_{P V}$ is proportional to the Epv and modules area APv; wind turbines WT whose electrical production $W_{W}$ is the result of the electrical production Ew multiplied by the number of turbines; inverter Inv which converts the direct current to alternating current; batteries Bat which can store electric energy and inverter-charger InvC which converts alternating current to direct current and viceversa. The excess of electricity produced by PV or WT which is not sold to the grid is wasted by a dissipator. The thermal part consists of conventional gas boiler GB that consumes fossil fuel $F_{G B}$ to produce heat; solar thermal collectors ST whose heat production $Q_{S T}$ is proportional to Est and the area Ast; a singleeffect absorption chiller ACH that uses heat and a small quantity of electricity to produce cooling $R_{A C H}$; and thermal energy storage for heating TSQ and cooling TSR, which can charge/discharge thermal energy. Components such as cogeneration module CM, converting the energy of fossil fuels $F_{C M}$ into electricity $W_{C M}$ and heat $Q_{C M}$, and reversible heat pumps HP, converting the electrical energy $E_{H P}$ into thermal energy either heating $Q_{н P}$ or cooling $R_{H P}$, enables the integration of electric and thermal parts. 


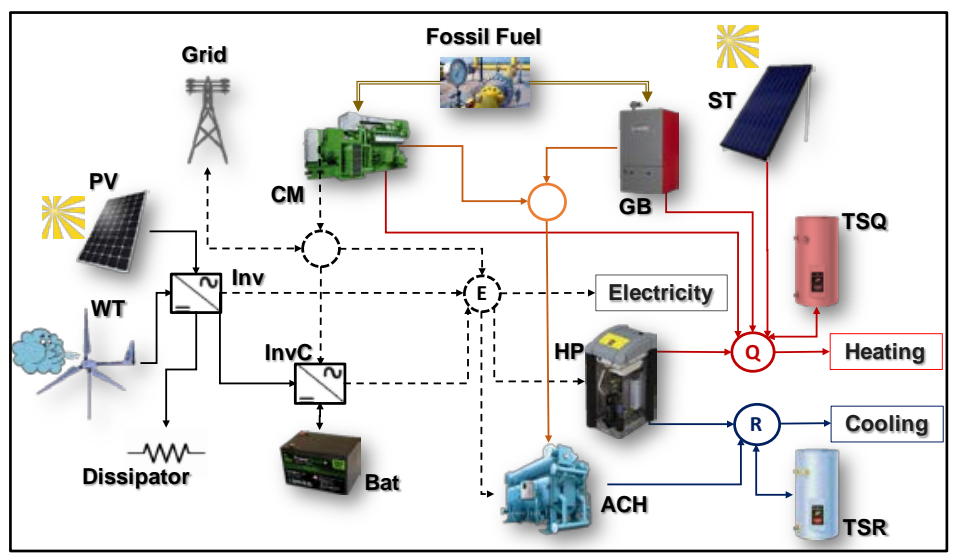

Figure 1. Superstructure containing all considered candidate technologies. Nodes are represented by circles.

Technical data: The components Comp of the superstructure are commercially available. The main technical parameters obtained from the manufacturers' catalogues are shown in Table 5.

GB, HP and ACH can be modulated up to nominal capacity. The efficiency $\eta_{G B}$ of conventional boiler was considered constant. Heat pump operates in heating mode assuming a constant coefficient of performance COP, or in cooling mode considering a constant Energy Efficiency Ratio EER with a constant cooling/heating capacity ratio $\beta$. Both COP and EER have been estimated considering the operational temperature of the reservoirs expected for Zaragoza (Spain), about $3^{\circ} \mathrm{C}$ in winter and $31^{\circ} \mathrm{C}$ in summer; moreover, the maximum operational set temperature for the application, about $60^{\circ} \mathrm{C}$ for DHW and $7^{\circ} \mathrm{C}$ for cooling water. The single effect absorption chiller operates with a constant $\mathrm{COP}_{\mathrm{ACH}}$.

For the inverter and inverter-charger, an oversizing factor of $20 \%$ was applied to size their capacity. Also, a constant efficiency $\eta$ was considered.

Regarding energy storage, for thermal energy storage tanks, the energy stored $S_{q}$ and $S_{r}$ for heating and cooling, respectively, were calculated at each time step (1 hour) taking into account the energy losses by applying a $\lambda$ factor. In the case of batteries, the technology is Ion-Lithium. The round trip efficiency $\eta_{r t}$, determines the energy losses during the charging and discharging process in each time step. Charging and discharging processes are not allowed simultaneously either in thermal energy storage tanks or in batteries. Further, a maximum deep of discharge $D O D$ is defined for batteries to avoid premature failures. During the batteries lifetime operation, the number of chargedischarge cycles has to be lower than the maximum number of cycles that that cause

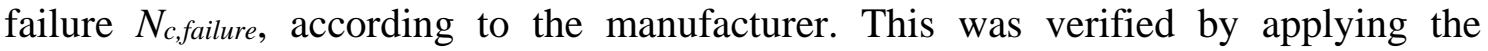
equivalent full cycle to failure ageing method [57]. Model of capacity [58] was applied to calculate the dynamic behaviour of Ion lithium batteries which take into account both, the maximum charge current stablished by manufacturer and the charge ratio $\alpha_{c}$ in A/Ah [59]. Taking into account that this study is based on representative days, for both thermal and electrical storage, the stored energy at the beginning of each representative day must be equal to the stored energy at the end of each representative day. 
In the case of the cogeneration module $\mathrm{CM}$, modulation varies depending on the manufacturer, for instance, it can modulate down to 50\% [60], and even down to 6\% subject to additional components [61]. A common practice to maintain a constant efficiency is to install several units which allow load control to be applied by shutting down individual engines while keeping the others at nearly-nominal load. For instance, when the CM set consists of 2 cogeneration modules, and each CM can modulate up to $50 \%$, the CM set can modulate up to $25 \%$. However, taking into account that modulate up to about $6 \%$ is possible, it could be a suitable approach to consider CM set partial load up to $15 \%$ for residential buildings applications where 2 or more cogeneration modules can be installed. On the other hand, for household applications, partial load of about $30 \%$ could be considered a good approach.

Small and micro cogeneration must provide primary energy savings (PES) to be considered as a high-efficiency cogeneration [62]. Therefore, PES was calculated and verified to accomplish the normative. More information about them can be found in Appendix A.

Economic data: The economic investment of the polygeneration system considers a project lifetime $n_{\text {proj }}=20$ years at interest rate $r=5 \%$. Then, the capital recovery factor $C R F=0.082 y^{-1}$ was applied to set the fixed annual cost of the investment. In addition, indirect costs were considered by applying a factor $F_{\text {ind }}$ of $20 \%$ over the total investment cost. Economic investment of each component was calculated from the unit cost $C_{u}$. A factor $F_{m}$ was defined to consider the installation and maintenance costs. This study offers an approach for the design of polygeneration systems, therefore average unit costs have been considered for each technology. Nevertheless, there is a difference between the household and the building because of the economy of scale, which have been considered for some components. Moreover, the available minimum capacity is a restriction for the installation of some components at some scales. For instance, absorption chiller was not considered as a candidate technology for household system. The VAT (Value-Added Tax) was applied, whose value is 0.21 for Spain (Peninsula). When the lifetime of the component $n_{\text {сотp }}$ is below to project lifetime, its net present value factor FNPV is calculated in order to take into account the total substitutions carried out throughout the installation's lifetime. All economic data are shown in Table 5. The electricity time-ofuse tariffs were applied in different scenarios based on economic data of the electricity marketer [33]. Also, it was considered a meter equipment rental cost $C_{\text {alqe }}$ and the electricity tax Taxe. In the case of natural gas costs, the contract depends on the annual gas consumption, which is related to the fixed cost $C_{f g}$. The variable cost of the natural gas $C_{v g}$ is proportional to the retail price $p_{g}$ [33]. Table 6 and 7 summarize the electricity and natural gas tariffs.

Environmental data: In order to evaluate the environmental impact, it was considered the $\mathrm{CO}_{2}$ eq emissions embodied in every component of the superstructure $\mathrm{CO}_{2} \mathrm{fix}$, based on the unit $\mathrm{CO}_{2}$ emissions $\mathrm{CO}_{2} \mathrm{U}$ of every component (Table 5). Further, $\mathrm{CO}_{2}$ emissions released due to the i) natural gas combustion, considering a constant value of 0.204 $\mathrm{kgCO}{ }_{2} \mathrm{eq} / \mathrm{kWh}$ [63], and ii) the hourly $\mathrm{CO}_{2}$ emissions due to electricity consumption from the grid [51] were considered as well. 
Table 5. Technical, economic and environmental data

\begin{tabular}{|c|c|c|c|c|c|c|c|c|c|c|c|c|}
\hline \multirow{3}{*}{ Comp } & \multirow{3}{*}{$\begin{array}{l}\text { Technical data } \\
\text { (Tech) }\end{array}$} & \multirow{3}{*}{$\begin{array}{c}\text { Min } \\
\text { Capacity } \\
{[*]}\end{array}$} & \multicolumn{6}{|c|}{ Economic data (Econ) } & \multirow{3}{*}{\begin{tabular}{|c|}
$\begin{array}{c}\text { Environmental } \\
\text { data (Env) }\end{array}$ \\
$\mathrm{CO}_{2} \mathrm{U}$ \\
{$\left[\mathrm{kgCO}_{2} \mathrm{eq}^{*}{ }^{*}\right]$} \\
\end{tabular}} & \multirow{2}{*}{\multicolumn{3}{|c|}{ References }} \\
\hline & & & \multicolumn{3}{|c|}{ Household } & \multicolumn{3}{|c|}{ Building } & & & & \\
\hline & & & $\begin{array}{c}\mathrm{Cu} \\
{[€ / *]}\end{array}$ & $F_{m}$ & $\begin{array}{c}\text { ncomp }_{\text {chears] }} \\
\text { [Yeas }\end{array}$ & $\begin{array}{c}\mathrm{Cu} \\
{[€ / *]}\end{array}$ & $F_{m}$ & $\begin{array}{c}\text { ncomp } \\
\text { [Years] }\end{array}$ & & (Tech) & (Econ) & (Env) \\
\hline PV & $\begin{array}{l}\eta_{\text {mp,ref }}=15.66 \% ; \\
\mu \text { Voc }=-0.32 \% /{ }^{\circ} \mathrm{C}\end{array}$ & $1.6 \mathrm{~m}^{2}$ & 113 & 1.8 & 20 & 113 & 0.9 & 20 & 161 & [44] & [64] & [65] \\
\hline WT & $\begin{array}{l}\text { Manufacturer } \\
\text { curve }\end{array}$ & $1 \mathrm{kWe}$ & 2360 & 2 & 20 & 2360 & 0.9 & 20 & 720 & {$[47,48]$} & {$[66]$} & $\begin{array}{c}{[67-} \\
69]\end{array}$ \\
\hline ST & $\begin{array}{c}\eta_{0}=0.801 ; \\
\mathrm{a}_{1}=3.188 \mathrm{~W} / \mathrm{m}^{2} \cdot \mathrm{K} ; \\
\mathrm{a}_{2}=0.011 \mathrm{~W} / \mathrm{m}^{2} \cdot \mathrm{K}^{2}\end{array}$ & $2 \mathrm{~m}^{2}$ & 257 & 1.5 & 20 & 257 & 1.5 & 20 & 95 & \multicolumn{2}{|c|}{$[45]$} & {$[70]$} \\
\hline $\mathrm{CM}$ & $\alpha_{w}=0.28 \alpha_{q}=0.56$ & $1 \mathrm{kWe}$ & 1150 & 0.7 & 10 & 1150 & 0.7 & 10 & 65 & [61] & [71] & [72] \\
\hline GB & $\eta_{b}=0.96$ & $20 \mathrm{kWt}$ & 80 & 0.5 & 15 & 80 & 0.5 & 20 & 10 & \multicolumn{2}{|c|}{ [73] } & [72] \\
\hline HP & $\mathrm{COP}=3.0 \mathrm{EER}=4.0$ & $3 \mathrm{kWt}$ & 500 & 0.5 & 20 & 400 & 0.5 & 20 & 160 & \multicolumn{2}{|c|}{$[74,75]$} & {$[72,76]$} \\
\hline $\mathrm{ACH}$ & $\mathrm{COP}=0.7$ & $17 \mathrm{kWt}$ & - & - & - & 485 & 1.5 & 20 & 165 & \multicolumn{2}{|c|}{ [77] } & {$[72,76]$} \\
\hline TSQ & $\lambda_{\mathrm{TSQ}}=1 \%$ & $2 \mathrm{kWht}$ & 283 & 0.1 & 15 & 212 & 0.1 & 15 & 31 & \multirow{2}{*}{\multicolumn{2}{|c|}{$[73,75]$}} & \\
\hline TSR & $\lambda_{\mathrm{TSR}}=3 \%$ & $1 \mathrm{kWht}$ & 325 & 0.1 & 15 & 257 & 0.1 & 15 & 62 & & & [76] \\
\hline Bat & $\begin{array}{c}\eta_{\mathrm{rt}}=0.95 ; \\
\mathrm{DOD}=90 \% ; \\
\mathrm{N}_{\mathrm{c}, \text { failure }}=2000\end{array}$ & $0.5 \mathrm{kWh}$ & 370 & 0.25 & 12 & 370 & 0.25 & 12 & 160 & \multicolumn{2}{|c|}{ [78] } & [79] \\
\hline Inv & $\eta_{\text {Inv }}=0.98$ & $0.8 \mathrm{kWe}$ & 400 & 0.00 & 15 & 400 & 0.00 & 15 & 191 & \multirow{2}{*}{\multicolumn{2}{|c|}{ [80-82] }} & [83] \\
\hline InvC & $\eta_{\text {InvC }}=0.94$ & $0.8 \mathrm{kWe}$ & 774 & 0.25 & 15 & 774 & 0.25 & 15 & 191 & & & \\
\hline
\end{tabular}

Table 6. Electricity tariffs in Spain (Peninsula) [33,84]

\begin{tabular}{|c|c|c|c|c|c|c|}
\hline \multirow{2}{*}{$\begin{array}{c}\text { Time-of-use } \\
\text { tariff }\end{array}$} & \multirow{2}{*}{$\begin{array}{c}\text { Contracted } \\
\text { power [kW] }\end{array}$} & \multirow{2}{*}{$\begin{array}{l}\text { Time } \\
\text { period }\end{array}$} & \multicolumn{2}{|c|}{ Hours } & \multirow{2}{*}{$\begin{array}{c}\text { cPct } \\
{[€ / \mathbf{k W} \cdot \mathbf{y r}]}\end{array}$} & \multirow{2}{*}{$\begin{array}{c}\text { cp } \\
{[€ / \mathbf{k W h}]}\end{array}$} \\
\hline & & & Winter & Summer & & \\
\hline \multirow{3}{*}{$\begin{array}{c}\text { Tariff } 2.0 \\
\text { DHS }\end{array}$} & \multirow{3}{*}{ Pct $<10$} & P1 & $14-23$ & $14-23$ & \multirow{3}{*}{47.816} & 0.173941 \\
\hline & & P2 & 1;8-13;24 & 1;8-13;24 & & 0.099554 \\
\hline & & P3 & $2-7$ & $2-7$ & & 0.076838 \\
\hline \multirow{12}{*}{ Tariff 3.0A } & \multirow{3}{*}{$15<$ Pct $<30$} & $\mathrm{P} 1$ & $19-22$ & $12-15$ & 41.951 & 0.192699 \\
\hline & & P2 & $9-18 ; 23-24$ & $9-11 ; 16-24$ & 25.17 & 0.172904 \\
\hline & & P3 & $1-8$ & $1-8$ & 16.78 & 0.129289 \\
\hline & \multirow{3}{*}{$30<\mathrm{Pct}<50$} & P1 & $19-22$ & $12-15$ & 41.951 & 0.188567 \\
\hline & & P2 & $9-18 ; 23-24$ & $9-11 ; 16-24$ & 25.17 & 0.168758 \\
\hline & & P3 & $1-8$ & $1-8$ & 16.78 & 0.125166 \\
\hline & \multirow{3}{*}{$50<$ Pct $<100$} & $\mathrm{P} 1$ & $19-22$ & $12-15$ & 41.951 & 0.185322 \\
\hline & & P2 & $9-18 ; 23-24$ & $9-11 ; 16-24$ & 25.17 & 0.165525 \\
\hline & & P3 & $1-8$ & $1-8$ & 16.78 & 0.121922 \\
\hline & \multirow{3}{*}{$100<$ Pct $<250$} & $\mathrm{P} 1$ & $19-22$ & $12-15$ & 41.951 & 0.183892 \\
\hline & & $\mathrm{P} 2$ & $9-18 ; 23-24$ & $9-11 ; 16-24$ & 25.17 & 0.164085 \\
\hline & & P3 & $1-8$ & $1-8$ & 16.78 & 0.120491 \\
\hline
\end{tabular}

Table 7. Natural gas tariffs in Spain (Peninsula) [33]

\begin{tabular}{|c|c|c|c|c|}
\hline Fuel & Tariff & Fix term [€/yr] & Variable term [€/kWh] & Annual consumption limit [kWh/yr] \\
\hline & 3.1 & 61.8 & 0.063125 & $\leq 5000$ \\
Natural & 3.2 & 112.2 & 0.05845 & $5000-50000$ \\
Gas (NG) & 3.3 & 650.64 & 0.050523 & $50000-100000$ \\
& 3.4 & 971.64 & 0.046843 & $>100000$ \\
\hline
\end{tabular}




\subsection{Optimization of the polygeneration system}

The design of the polygeneration system is carried out by solving a MILP model developed in the optimizer software Lingo [85]. A single optimization is carried out minimizing the total annual cost TAC, expressed in $€ / y r$, which is composed of the investment annual cost CIA and operational cost $C_{o p}$.

Minimize TAC

$T A C=C I A+C_{o p}$

The operational annual cost $C_{o p}$ is the sum of the electricity bill cost $C_{e}$ and the fuel consumption cost $C_{g}$.

$C_{o p}=C_{e}+C_{g}$

The electricity bill $C_{e}$ is composed of a fixed part $C_{f i x e}$, and the variable cost $C_{v_{e}}$. $C_{f i x e}$ is proportional to contracted power Pct at $c P c t$ price in $€ / \mathrm{kWe}$. $C_{v_{e}}$ is calculated based on the electricity consumption $E p$ at $c p_{e}$ price and the sale electricity Es at $c S_{e}$ price. Values of $c p_{e}$ and $c s e$ in $€ / \mathrm{kWh}$ depend on time-of-use tariff. A specific tariff is applied depending on the day $d$ and the hour $h$ (Table 6). Besides different taxes and fixed costs such as the electricity tax $\operatorname{Tax}_{e}=0.0513$ and the equipment rental cost $C_{a q_{e}}$ of $9.72 € /$ yr for households and $16.32 € / y r$ for buildings. The contract power Pct is selected by using binary variable $Y_{P c t n}$, taking into account that neither purchased electricity nor sale electricity can exceed the contracted power.

$C_{e}=\left(\left(C_{f i x_{e}}+C_{v_{e}}\right) \cdot\left(1+\operatorname{Tax}_{e}\right)+C_{a l q_{e}}\right) \cdot(1+V A T)$

$C_{f i x_{e}}=\sum_{i=1}^{3} c P c t_{i} \cdot P c t_{i}$

$P c t_{\text {nom }}=\left[P c t_{1} \ldots P c t_{n}\right]$

$P c t=\left[P c t_{\text {nom }} \cdot Y_{P c t 1} ; P c t_{\text {nom }} \cdot Y_{P c t 2} ; P c t_{\text {nom }} \cdot Y_{P c t 3}\right]$

$\operatorname{Pct}(n) \geq(E p(d, h)+E s(d, h))_{n}$

$C_{v_{e}}=\sum_{d=1}^{N_{r e p}} \omega_{d} \cdot\left(\sum_{h=1}^{24}\left(c p_{e}(h) \cdot(E p(h))-c s_{e}(h) \cdot E s(h)\right)\right)_{d}$

$C_{g}$ is the natural gas bill cost which consists of a fixed part related to the annual natural gas consumption $C_{f i x g}$ and a variable part proportional to the natural gas consumption $C_{v_{g}}$.

$C_{g}=\left(C_{f i x_{g}}+C_{v_{g}}\right) \cdot(1+V A T)$

$C_{v_{g}}=\sum_{d=1}^{N_{r e p}} \omega_{d} \cdot\left(\sum_{h=1}^{24} c p_{g} \cdot F_{g}(h)\right)_{d}$

The environmental impact TCE, expressed in $\mathrm{kgCO} 2 \mathrm{eq} / \mathrm{yr}$, is evaluated simultaneously for each economic optimum, but TCE is not an objective function. It is composed of a fixed part $\mathrm{CO}_{2}$ fix corresponding to the $\mathrm{CO}_{2}$ emissions embodied in the components and a variable part $\mathrm{CO} 2_{\text {ope }}$ corresponding to the $\mathrm{CO}_{2}$ emissions due to the natural gas consumption and/or electricity consumption from the grid during the operation system.

$T C E=C O 2_{\text {fix }}+C O 2_{\text {ope }}$ 


$$
\begin{aligned}
& \mathrm{CO2}_{\text {fix }}=\sum_{j} \mathrm{CO}_{2} U_{j} \cdot \operatorname{Cap}_{j} \cdot\left(1+\operatorname{Repl}_{j}\right) / n_{\text {proj }} \\
& \mathrm{CO}_{\text {ope }}=\sum_{d=1}^{N_{\text {rep }}} \omega_{d} \cdot\left(\sum_{h=1}^{24}\left(\operatorname{CO2}_{g} \cdot F_{g}(h)+\operatorname{CO2}_{\text {grid }}(h) \cdot E p(h)-\mathrm{CO}_{\text {grid }}(h) \cdot E s(h)\right)\right)_{d}
\end{aligned}
$$

$R e p l$ is the number of replacements carried out during the lifetime of the installation for every component, $\mathrm{CO}_{2} g$ is the $\mathrm{CO}_{2}$ emissions associated to the combustion of the natural gas in $\mathrm{kgCO}_{2} \mathrm{eq} / \mathrm{kWh}$, and $\mathrm{CO}_{2}$ grid are the $\mathrm{CO}_{2}$ emissions associated to the electricity from the grid in each hour, in $\mathrm{kgCO} 2 \mathrm{eq} / \mathrm{kWh}$.

Subject to:

\section{Balance equations}

Energy balance equations are carried out in each node $m$ of the superstructure (Figure 1). $E$ represents energy flows of heat $Q$, cool $R$ or electricity $W$.

$$
\sum_{m}\left(E_{\text {in }}^{m}-E_{\text {out }}^{m}\right)=0
$$

\section{Equipment Efficiency}

The efficiency of each component of the superstructure has been considered. $F$ represents the fuel consumption of the component.

GB: $\eta_{G B} \cdot F_{G B}-Q_{G B}=0$

HP: $Q_{H P}-W_{H P} \cdot C O P=0$

HP: $R_{H P}-W_{H P} \cdot E E R=0$

$\mathrm{CM}: \alpha_{w} \cdot F_{C M}-W_{C M}=0$

$\mathrm{CM}: \alpha_{q} \cdot F_{C M}-Q_{C M}=0$

$\mathrm{ACH}: R_{A C H}=C O P_{A C H} \cdot Q_{A C H}$

Equipment's capacities:

For renewable energy production components, the aim is to find size of the PV modules $A P V$, solar thermal collectors $A s T$ and the number of wind turbines $N_{W T}$

$\mathrm{PV}: W_{P V}=E_{P V} \cdot A_{P V}$

$\mathrm{ST}: Q_{S T}=E_{S T} \cdot A_{S T}$

$\mathrm{WT}: W_{W}=E_{W} \cdot N_{W T}$

For each component, the energy production is equal to or lower than its nominal capacity. In the case of energy storage, its stored energy must be equal to or lower than their nominal capacity

$E_{j} \leq \operatorname{Cap}_{j}$

$S_{j} \leq \operatorname{Cap}_{j}$

Partial load PL of CM is considered by applying a binary variable YoN. Capmax is the maximum capacity allowed for CM. It can work in any time as being required. 


$$
W_{C M}-P L \cdot \operatorname{Cap}_{C M} \geq-\operatorname{Cap}_{\max } \cdot\left(1-Y_{O N}\right)
$$

$W_{C M} \leq \operatorname{Cap}_{\max } \cdot Y_{O N}$

In addition, different legal restrictions were considered.

\section{Results}

The optimization of the polygeneration system for individual and collective installations was carried out by applying legal restrictions based on both regulations RD 900/2015 and RD 244/2019. Three different scenarios have been studied: i) Scenario 1: Electricity sale is not allowed, which corresponds to the case of self-consumption type 1 in both regulations; ii) Scenario 2: Electricity sale is allowed at spot price; iii) Scenario 3: Electricity sale is allowed at $80 \%$ purchase price. As already explained, scenarios 2 and 3 are proposed as particular examples of the type 2 self-consumption in both regulations $[29,30]$.

All runs were performed on an Intel Core i5-6200 CPU @ 2.3 GHz, with a memory of 8 GB and 64-bit system. The runtime was about 7 minutes. The number of variables is 36200, within them, 700 are integer variables.

A conventional energy system consisting of a gas boiler to attend heating demands, a mechanical chiller driven by electricity from the grid to attend only cooling demands, and electricity also purchased from the grid to cover the electrical demand of appliances is considered as a reference scenario for both cases. This system was also optimized and their results are presented in each table of results so as to be compared. The rest of scenarios consider reversible heat pump. It was assumed the same unit cost for the mechanical chiller and heat pump.

\subsection{Individual installation: Household}

\subsubsection{Optimization of the polygeneration system for a household based on RD 900/2015}

The optimization of the total annual cost of the superstructure for a household was carried out under the legal restrictions based on the RD 900/2015. Tables 8 and 9 show the obtained results for the optimal design of a polygeneration system for a household. Figure 2 shows the optimal configuration. For scenario 1, this includes PV, HP, GB and TSR whereas for scenarios 2 and 3 only HP, GB and TSR were included. The results of scenarios 2 and 3 mean that for a household user, it is not profitable at all to sell electricity (type 2 self-consumption), because in those conditions, the potential electricity bill savings and revenues from electricity sale (from the PV panels) do not compensate the self-consumption taxes to pay.

By comparing the reference scenario with scenario 1, a significant reduction of about $36 \%$ in economic operational costs was achieved, but in terms of total annual cost a reduction of about $10 \%$ was achieved. The installation of PV panels and TSR enable the contracted power to be reduced up to $50 \%$ with respect to the reference scenario. In terms of environmental impact, the total $\mathrm{CO}_{2}$ emissions were reduced about $50 \%$. In this scenario, the produced PV electricity that is not self-consumed is dissipated at zero cost. 

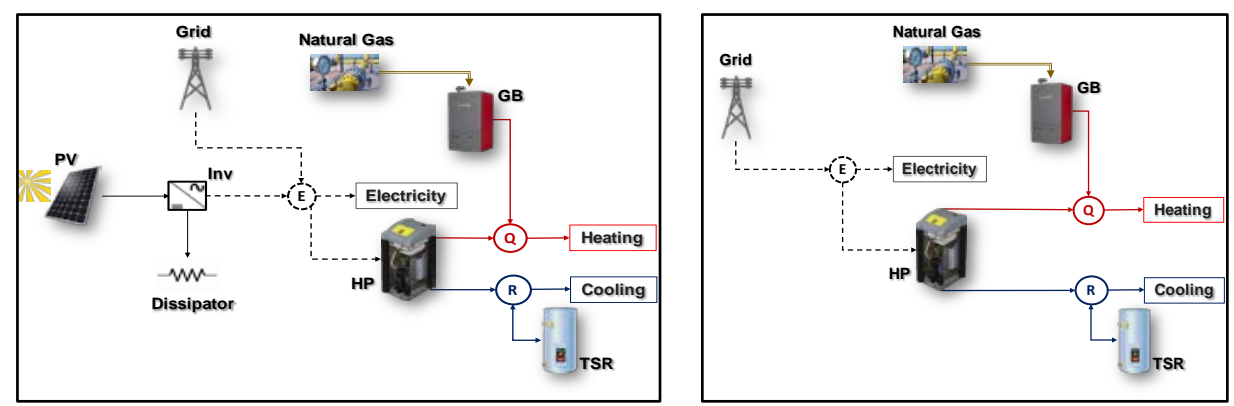

Figure 2. Optimal configuration of a polygeneration system based on RD 900/2015 for a household. Scenario 1 (Left) and Scenarios 2 and 3 (Right)

On the other hand, when the user accepts to sell electricity to the grid, under the application of RD 900/2015, the installation of PV panels is not profitable because the compulsory self- consumption taxes to pay are not compensated with the revenues obtained from the electricity sale, impeding in fact that self-consumption with electricity sale under this regulation could be profitable. Table 9 shows the optimal design of scenarios 2-3. The installation of reversible HP and TSR enable the contracted power to be reduced about $25 \%$. Although a self-consumption system was not installed, there was a reduction in the total economic cost and $\mathrm{CO}_{2}$ emissions of about $9 \%$ and $39 \%$ respectively, with respect to the reference scenario. These results show the advantages of using reversible $\mathrm{HP}$ to reduce $\mathrm{CO}_{2}$ emissions as well as its combination with TSR to reduce economic cost. The natural gas consumption decreases about $90 \%$ in every scenario with respect to reference scenario thanks to the use of reversible heat pump.

Table 8. Results of the optimization of the polygeneration system for a household based on RD 900/2015. Reference scenario and scenario 1

\begin{tabular}{|c|c|c|c|c|c|c|}
\hline \multirow[b]{2}{*}{ Technology $\boldsymbol{j}$} & \multicolumn{3}{|c|}{ Reference scenario } & \multicolumn{3}{|c|}{ Scenario 1} \\
\hline & Installed Cap & $\begin{array}{l}\mathrm{CIAj} \\
{[€ / \mathrm{yr}]}\end{array}$ & {$\left[\mathrm{kgCO}_{2} \mathrm{eq} / \mathrm{yr}\right]$} & Installed Cap & $\begin{array}{l}\text { CIAj } \\
{[€ / \mathbf{y r}]}\end{array}$ & $\begin{array}{c}\mathrm{CO}_{2} \mathrm{fix}_{\mathbf{j}} \\
{[\mathrm{kgCO}} \\
2 \mathrm{eq} / \mathrm{yr}]\end{array}$ \\
\hline Pct [kW] & 2.3 & - & - & 1.15 & - & - \\
\hline PV & - & - & - & $4.9 \mathrm{~m}^{2}$ & 181 & 39 \\
\hline HP & $6.5 \mathrm{kWt}$ & 569 & 52 & $5.5 \mathrm{kWt}$ & 482 & 44 \\
\hline GB & $20 \mathrm{kWt}$ & 414 & 20 & $20 \mathrm{kWt}$ & 414 & 20 \\
\hline TSR & - & - & - & $1.3 \mathrm{kWht}$ & 81 & 8 \\
\hline INV & - & - & - & $1.0 \mathrm{~kW}$ & 63 & 17 \\
\hline \multicolumn{2}{|c|}{$\begin{array}{r}\text { Investment annual cost / } \\
\text { Embodied } \mathrm{CO}_{2} \text { emissions }\end{array}$} & 983 & 72 & - & 1221 & 129 \\
\hline & $\begin{array}{c}\text { Consumption } \\
{[\mathrm{kWh} / \mathrm{yr}]}\end{array}$ & $\begin{array}{c}\text { Energy } \\
\text { cost }[€ / y r]\end{array}$ & $\begin{array}{l}\mathrm{CO}_{2} \text { emissions } \\
{\left[\mathrm{kgCO}_{2} \mathrm{eq} / \mathrm{yr}\right]}\end{array}$ & $\begin{array}{l}\text { Consumption } \\
{[\mathrm{kWh} / \mathrm{yr}]}\end{array}$ & $\begin{array}{l}\text { Energy } \\
\operatorname{cost}[€ / y r]\end{array}$ & $\begin{array}{c}\mathrm{CO}_{2} \\
\text { emissions } \\
{\left[\mathrm{kgCO}_{2} \mathrm{eq} / \mathrm{yr}\right]}\end{array}$ \\
\hline Purchased electricity & 3230 & 712 & 668 & 3653 & 704 & 757 \\
\hline Natural gas & 6075 & 542 & 1242 & 550 & 94 & 112 \\
\hline \multicolumn{2}{|c|}{$\begin{array}{l}\text { Operational Economic cost// } \\
\text { Operational } \mathrm{CO}_{2} \text { emissions }\end{array}$} & 1254 & 1910 & - & 798 & 869 \\
\hline \multicolumn{2}{|c|}{$\begin{array}{r}\text { Total Economic cost/ } \begin{array}{r}\text { Total } \mathrm{CO}_{2} \\
\text { emissions }\end{array} \\
\end{array}$} & 2236 & 1982 & - & 2019 & 998 \\
\hline
\end{tabular}


Table 9. Results of the optimization of the polygeneration system for a household based on RD 900/2015. Scenarios 2 and 3

\begin{tabular}{|c|c|c|c|}
\hline \multirow{2}{*}{ Technology $j$} & \multicolumn{3}{|c|}{ Scenario 2-3 } \\
\hline & Installed Cap & CIAj $[€ / y r]$ & $\mathrm{CO}_{2} \mathrm{fix}_{\mathrm{j}}\left[\mathrm{kgCO}_{2} \mathrm{eq} / \mathrm{yr}\right]$ \\
\hline Pct $[k W]$ & 1.725 & - & - \\
\hline PV & $0.0 \mathrm{~m}^{2}$ & 0 & 0 \\
\hline HP & $5.7 \mathrm{kWt}$ & 497 & 47 \\
\hline GB & $20 \mathrm{kWt}$ & 414 & 20 \\
\hline TSR & $1 \mathrm{kWht}$ & 62 & 3 \\
\hline INV & $0.0 \mathrm{~kW}$ & 0 & 0 \\
\hline \multicolumn{2}{|c|}{ Investment annual cost / Embodied $\mathrm{CO}_{2}$ emissions } & 973 & 71 \\
\hline & Consumption [kWh/yr] & Energy cost $[€ / y r]$ & $\mathrm{CO}_{2}$ emissions $\left[\mathrm{kgCO}_{2} \mathrm{eq} / \mathrm{yr}\right]$ \\
\hline $\begin{array}{l}\text { Purchased } \\
\text { Electricity }\end{array}$ & 5010 & 979 & 1022 \\
\hline Natural gas & 524 & 92 & 107 \\
\hline \multicolumn{2}{|c|}{$\begin{array}{l}\text { Operational Economic cost/ Operational } \mathrm{CO}_{2} \\
\text { emissions }\end{array}$} & 1071 & 1129 \\
\hline \multicolumn{2}{|c|}{ Total Economic cost/ Total $\mathrm{CO}_{2}$ emissions } & 2043 & 1200 \\
\hline
\end{tabular}

\subsubsection{Optimization of the polygeneration system for a household based on RD 244/2019}

The optimization of the total annual cost of the superstructure for a household is carried out. The optimal configuration is shown in the figure 3. This is the same for the three different considered scenarios which includes PV, HP, GB and TSR, the only difference is that an electricity dissipator is not required when sale of electricity is allowed. Tables 10 and 11 show the optimal design of a polygeneration system for a household by applying RD 244/2019.
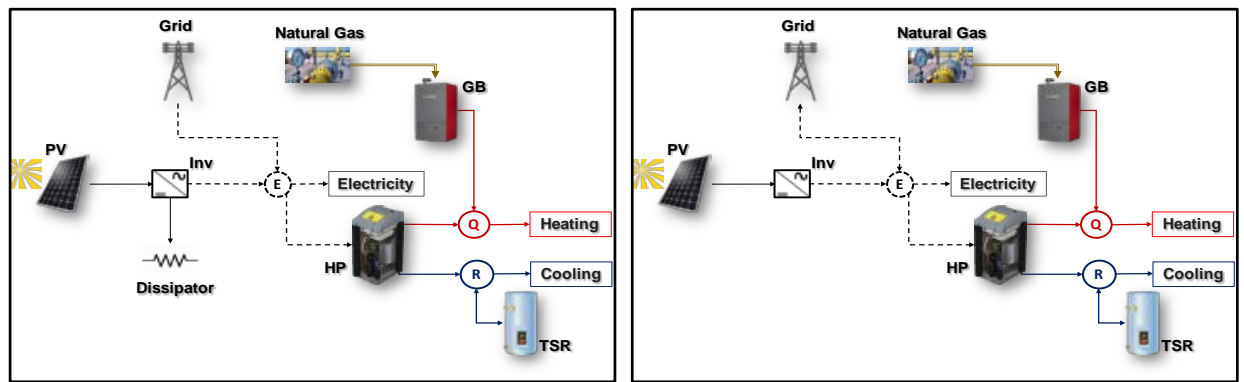

Figure 3. Optimal configuration of a polygeneration system for a household based on RD 244/2019. Scenario 1 (left), scenarios 2 and 3 (right).

The results of scenario 1 based on RD 900/2015 and RD244/2019 are the same, since there is no application of self-consumption taxes in both cases. On the other hand, unlike scenarios 2 and 3 based on RD 900/2015, in this case the installation of a polygeneration system based on PV and HP is profitable. Both scenarios 2 and 3 present the same configuration. The achievements in total economic and environmental costs are quite similar to scenario 1. By comparing scenario 1 with scenarios 2 and 3, the fact of selling electricity increased the PV and HP capacity about 10\% and 4\% respectively, and decreased the TSR capacity about $23 \%$. However, in absolute terms, these variations were not significant in this size scale. Regarding the installation of PV panels, these covered only about $15 \%$ of the total available horizontal surface. The obtained results show that for 1 household the possibility of selling electricity to the grid does not provide a 
significant economic benefit but operational flexibility without dissipating electrical energy.

Table 10. Results of the optimization of the polygeneration system for a household based on RD 244/2019. Reference scenario and scenario 1

\begin{tabular}{|c|c|c|c|c|c|c|}
\hline \multirow[b]{2}{*}{ Technology $\boldsymbol{j}$} & \multicolumn{3}{|c|}{ Reference scenario } & \multicolumn{3}{|c|}{ Scenario 1} \\
\hline & Installed Cap & $\begin{array}{l}\text { CIAj } \\
{[€ / \mathrm{yr}]}\end{array}$ & $\begin{array}{c}\mathrm{CO}_{2} \mathrm{fix}_{\mathrm{j}} \\
{\left[\mathrm{kgCO} \mathrm{O}_{2} \mathrm{eq} / \mathrm{yr}\right]}\end{array}$ & Installed Cap & CIAj $[€ / y r]$ & $\begin{array}{c}\mathrm{CO}_{2} \mathrm{fix}_{\mathbf{j}} \\
{[\mathrm{kgCO}} \\
2 \mathrm{eq} / \mathrm{yr}]\end{array}$ \\
\hline Pct [kW] & 2.3 & - & - & 1.15 & - & - \\
\hline PV & - & - & - & $4.9 \mathrm{~m}^{2}$ & 181 & 39 \\
\hline HP & $6.5 \mathrm{kWt}$ & 569 & 52 & $5.5 \mathrm{kWt}$ & 482 & 44 \\
\hline GB & $20 \mathrm{kWt}$ & 414 & 20 & $20 \mathrm{kWt}$ & 414 & 20 \\
\hline TSR & - & - & - & $1.3 \mathrm{kWht}$ & 81 & 8 \\
\hline INV & - & - & - & $1.0 \mathrm{~kW}$ & 63 & 17 \\
\hline \multicolumn{2}{|c|}{$\begin{array}{l}\text { Investment annual cost / Embodied } \\
\mathrm{CO}_{2} \text { emissions }\end{array}$} & 983 & 72 & - & 1221 & 129 \\
\hline & $\begin{array}{l}\text { Consumption } \\
{[\mathrm{kWh} / \mathrm{yr}]}\end{array}$ & $\begin{array}{l}\text { Energy } \\
\text { cost }[€ / y r]\end{array}$ & $\begin{array}{l}\mathrm{CO}_{2} \text { emissions } \\
{\left[\mathrm{kgCO}_{2} \mathrm{eq} / \mathrm{yr}\right]}\end{array}$ & $\begin{array}{l}\text { Consumption } \\
{[\mathrm{kWh} / \mathrm{yr}]}\end{array}$ & $\begin{array}{c}\text { Energy cost } \\
{[€ / \mathrm{yr}]}\end{array}$ & $\begin{array}{l}\mathrm{CO}_{2} \text { emissions } \\
{\left[\mathrm{kgCO}_{2} \mathrm{eq} / \mathrm{yr}\right]}\end{array}$ \\
\hline Purchased electricity & 3230 & 712 & 668 & 3653 & 704 & 757 \\
\hline Natural gas & 6075 & 542 & 1242 & 550 & 94 & 112 \\
\hline \multicolumn{2}{|c|}{$\begin{array}{l}\text { Operational Economic cost/ } \\
\text { Operational } \mathrm{CO}_{2} \text { emissions }\end{array}$} & 1254 & 1910 & - & 798 & 869 \\
\hline \multicolumn{2}{|c|}{$\begin{array}{l}\text { Total Economic cost/ Total } \mathrm{CO}_{2} \\
\text { emissions }\end{array}$} & 2236 & 1982 & - & 2019 & 998 \\
\hline
\end{tabular}

Table 11. Results of the optimization of the polygeneration system for a household based on RD 244/2019. Scenarios 2 and 3

\begin{tabular}{|c|c|c|c|}
\hline \multirow{2}{*}{ Technology $j$} & \multicolumn{3}{|c|}{ Scenario 2-3 } \\
\hline & Installed Cap & CIAj [€/yr] & $\mathrm{CO}_{2} \mathrm{fix}_{\mathbf{j}}\left[\mathrm{kgCO} \mathrm{O}_{2} \mathrm{eq} / \mathrm{yr}\right]$ \\
\hline Pct $[k W]$ & 1.15 & - & - \\
\hline PV & $5.4 \mathrm{~m}^{2}$ & 199 & 43 \\
\hline HP & $5.7 \mathrm{kWt}$ & 497 & 45 \\
\hline GB & $20 \mathrm{kWt}$ & 414 & 20 \\
\hline TSR & $1 \mathrm{kWht}$ & 62 & 6 \\
\hline INV & $1 \mathrm{~kW}$ & 70 & 19 \\
\hline \multicolumn{2}{|c|}{ Investment annual cost / Embodied $\mathrm{CO}_{2}$ emissions } & 1242 & 134 \\
\hline & Consumption [kWh/yr] & Energy cost [€/yr] & $\mathrm{CO}_{2}$ emissions $\left[\mathrm{kgCO}_{2} \mathrm{eq} / \mathrm{yr}\right]$ \\
\hline Purchased electricity & 3550 & 686 & \multirow{2}{*}{726} \\
\hline Sold electricity & 52 & -5 & \\
\hline Natural gas & 550 & 94 & 112 \\
\hline \multicolumn{2}{|c|}{ Operational Economic cost/ Operational $\mathrm{CO}_{2}$ emissions } & 776 & 839 \\
\hline \multicolumn{2}{|c|}{ Total Economic cost/ Total $\mathrm{CO}_{2}$ emissions } & 2017 & 973 \\
\hline
\end{tabular}

\subsection{Collective installation: Residential building}

By applying the legal restrictions based on the aforementioned regulations, the optimization of the polygeneration systems for residential building leads to the optimal configuration shown in the figure 4, which included CM, PV, HP, GB and TSR, and in some scenarios, TSQ as well. An electricity dissipator was required in scenario 1 when there was a surplus of produced PV electricity that was not self-consumed and in scenario 3 by applying RD 244/2019, due to the technical restriction which does not allow to sell electricity above the contracted power (Eq. 8). Note that only electricity which come from renewable energy can be sold, therefore, the electricity produced by CM is only for selfconsumption. In all cases, primary energy savings $P E S$ were positive. 

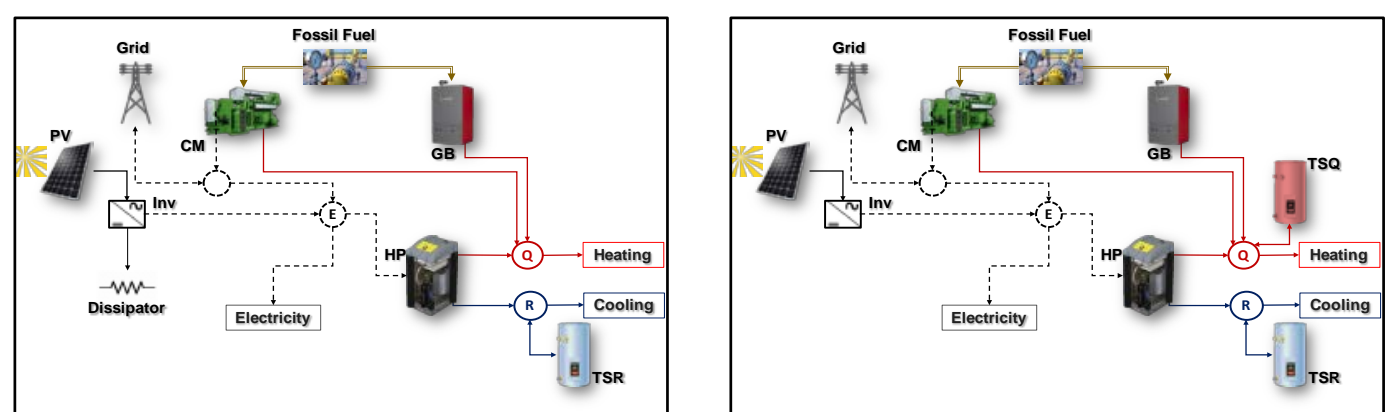

Figure 4. Optimal configuration of a polygeneration system for a residential building based on RD 900/2015 and RD 244/2019. Left: Scenarios 1 and 2 (RD 900/2015) and scenario 1 and 3 (RD 244/2019). Right: Scenario 3 (RD 900/2015) and scenario 2 (RD 244/2019).

3.2.1 Optimization of the polygeneration system for a residential building based on $R D$ 900/2015

Tables 12 and 13 show the optimal design of a polygeneration system for a residential building composed of 50 dwellings, by applying legal restrictions based on RD 900/2015.

The contracted power for the collective installation was the same for scenarios 1, 2 and 3 , with a significant reduction of about $50 \%$ with respect to the reference scenario. This is mainly due to the installation of the CM and PV panels. Regarding equipment capacity, the installation of reversible HP instead of a mechanical chiller enables the reduction of the GB capacity. Likewise, the installation of TSR enables the HP capacity reduction. In economic terms, from the reference scenario to scenario 1 there was a reduction of about $27 \%$ and $10 \%$ in the operational and total annual costs, respectively. From scenario 2 to scenario 3 there was a reduction of about $10 \%$ and $1 \%$ in the operational and total annual costs, respectively. On the other hand, from the environmental point of view, from reference scenario to scenario 1 there was a reduction of about $16 \%$ and $14 \%$ in the operational and total $\mathrm{CO}_{2}$ emissions respectively. From scenario 1 to 2 there was a reduction below $1 \%$ in both operational and total $\mathrm{CO}_{2}$ emissions. From scenario 2 to 3 there was a reduction of about $4 \%$ and $2 \%$ in the operational and total $\mathrm{CO}_{2}$ emissions, respectively. In scenario 1 , there was no dissipation of PV electricity, which means that all produced PV electricity was self-consumed. Under this regulation there is an important limitation to reach significant economic and environmental savings due to the selfconsumption taxes to pay and to the fact that the installed capacity of the renewable energy and cogeneration technologies cannot exceed the contracted power from the grid.

Table 12. Results of the optimization of the polygeneration system by applying the RD 900/2015 for a residential building. Reference scenario and scenario 1

\begin{tabular}{|c|c|c|c|c|c|c|}
\hline \multirow[b]{2}{*}{ Technology j } & \multicolumn{3}{|c|}{ Reference scenario } & \multicolumn{3}{|c|}{ Scenario 1} \\
\hline & Installed Cap & $\mathrm{CIA}_{\mathrm{j}}[€ / \mathrm{yr}]$ & $\begin{array}{c}\mathrm{CO}_{2} \mathrm{fix}_{\mathbf{j}} \\
{[\mathrm{kgCO}} \\
{[\mathrm{kgeq} / \mathrm{yr}]}\end{array}$ & Installed Cap & CIAj [€/yr] & $\begin{array}{c}\mathrm{CO}_{2} \mathrm{fix}_{\mathrm{j}} \\
{\left[\mathrm{kgCO} \mathrm{O}_{2} \mathrm{eq} / \mathrm{yr}\right]}\end{array}$ \\
\hline Pct $_{i}[k W]$ & $110.851_{1,2} / 20.785_{3}$ & - & - & $55.4261,2,3$ & - & - \\
\hline $\mathbf{C M}$ & - & - & - & $8 \mathrm{kWe}$ & 2941 & 52 \\
\hline PV & - & - & - & $199 \mathrm{~m}^{2}$ & 5006 & 1605 \\
\hline HP & $325 \mathrm{kWt}$ & 22747 & 2603 & $287 \mathrm{kWt}$ & 20083 & 2298 \\
\hline GB & $274 \mathrm{kWt}$ & 3824 & 137 & $98 \mathrm{kWt}$ & 1375 & 49 \\
\hline TSR & - & - & - & $44 \mathrm{kWht}$ & 2170 & 276 \\
\hline INV & - & - & - & $37 \mathrm{~kW}$ & 2576 & 713 \\
\hline $\begin{array}{r}\text { Investment annua } \\
\text { em }\end{array}$ & t / Embodied $\mathrm{CO}_{2}$ & 26571 & 2740 & - & 34152 & 4993 \\
\hline
\end{tabular}




\begin{tabular}{|c|c|c|c|c|c|c|}
\hline & $\begin{array}{c}\text { Consumption } \\
{[\mathrm{kWh} / \mathrm{yr}]}\end{array}$ & $\begin{array}{c}\text { Energy } \\
\text { cost }[€ / y r]\end{array}$ & $\begin{array}{l}\mathrm{CO}_{2} \text { emissions } \\
{\left[\mathrm{kgCO}_{2} \mathrm{eq} / \mathrm{yr}\right]}\end{array}$ & $\begin{array}{c}\text { Consumption } \\
{[\mathrm{kWh} / \mathrm{yr}]}\end{array}$ & $\begin{array}{c}\text { Energy cost } \\
{[€ / \mathrm{yr}]}\end{array}$ & $\begin{array}{l}\mathrm{CO}_{2} \text { emissions } \\
{\left[\mathrm{kgCO}_{2} \mathrm{eq} / \mathrm{yr}\right]}\end{array}$ \\
\hline Purchased electricity & 161495 & 42681 & 33341 & 84905 & 26275 & 17972 \\
\hline Natural gas & 303757 & 18189 & 62088 & 302829 & 18136 & 61898 \\
\hline \multicolumn{2}{|c|}{$\begin{array}{l}\text { Operational Economic cost/ Operational } \\
\mathrm{CO}_{2} \text { emissions }\end{array}$} & 60869 & 95429 & - & 44411 & 79870 \\
\hline \multicolumn{2}{|c|}{$\begin{array}{l}\text { Total Economic cost/ Total } \mathrm{CO}_{2} \\
\text { emissions }\end{array}$} & 87440 & 98169 & - & 78563 & 84863 \\
\hline
\end{tabular}

Table 13. Results of the optimization of the polygeneration system by applying the RD 900/2015 for a residential building. Scenarios 2 and 3.

\begin{tabular}{|c|c|c|c|c|c|c|}
\hline \multirow[b]{2}{*}{ Technology $\mathbf{j}$} & \multicolumn{3}{|c|}{ Scenario 2} & \multicolumn{3}{|c|}{ Scenario 3} \\
\hline & Installed Cap & $\mathbf{C I A}_{\mathbf{j}}[€ / \mathbf{y r}]$ & $\begin{array}{c}\mathrm{CO}_{2} \mathrm{fix}_{\mathrm{j}} \\
{\left[\mathrm{kgCO}{ }_{2} \mathrm{eq} / \mathrm{yr}\right]}\end{array}$ & Installed Cap & CIAj [€/yr] & $\begin{array}{c}\mathrm{CO}_{2} \mathrm{fix}_{\mathbf{j}} \\
{\left[\mathrm{kgCO}{ }_{2} \mathrm{eq} / \mathrm{yr}\right]}\end{array}$ \\
\hline Pcti $_{i}[k W]$ & $55.426_{1,2,3}$ & - & - & $55.426_{1,2,3}$ & - & - \\
\hline $\mathbf{C M}$ & $8 \mathrm{kWe}$ & 2941 & 52 & $6 \mathrm{kWe}$ & 2206 & 39 \\
\hline PV & $202 \mathrm{~m}^{2}$ & 5060 & 1623 & $317 \mathrm{~m}^{2}$ & 7954 & 2551 \\
\hline HP & $288 \mathrm{kWt}$ & 20134 & 2304 & $297 \mathrm{kWt}$ & 20751 & 2375 \\
\hline GB & $98 \mathrm{kWt}$ & 1375 & 49 & $106 \mathrm{kWt}$ & 1488 & 53 \\
\hline TSQ & $0.0 \mathrm{kWht}$ & 0 & 0 & $2 \mathrm{kWht}$ & 80 & 6 \\
\hline TSR & 43 kWht & 2103 & 267 & $27 \mathrm{kWht}$ & 1292 & 164 \\
\hline INV & $38 \mathrm{~kW}$ & 2604 & 721 & $58 \mathrm{~kW}$ & 4094 & 1133 \\
\hline \multicolumn{2}{|c|}{$\begin{array}{l}\text { Investment annual cost / Embodied } \\
\mathrm{CO}_{2} \text { emissions }\end{array}$} & 34218 & 5016 & - & 37865 & 6321 \\
\hline & $\begin{array}{l}\text { Consumption } \\
\text { [kWh/yr] }\end{array}$ & $\begin{array}{c}\text { Energy cost } \\
{[€ / \mathrm{yr}]}\end{array}$ & $\begin{array}{l}\mathrm{CO}_{2} \text { emissions } \\
{\left[\mathrm{kgCO}_{2} \mathrm{eq} / \mathrm{yr}\right]}\end{array}$ & $\begin{array}{c}\text { Consumption } \\
{[\mathrm{kWh} / \mathrm{yr}]}\end{array}$ & $\begin{array}{c}\text { Energy cost } \\
{[€ / \mathrm{yr}]}\end{array}$ & $\begin{array}{l}\mathrm{CO}_{2} \text { emissions } \\
{\left[\mathrm{kgCO}_{2} \mathrm{eq} / \mathrm{yr}\right]}\end{array}$ \\
\hline Purchased electricity & 84687 & 26260 & \multirow{2}{*}{17654} & 82873 & 26699 & \multirow{2}{*}{11173} \\
\hline Sold electricity & 1046 & -92 & & 33994 & -6008 & \\
\hline Natural gas & 303441 & 18171 & 62023 & 319647 & 19089 & 65336 \\
\hline \multicolumn{2}{|c|}{$\begin{array}{l}\text { Operational Economic cost/ } \\
\text { Operational } \mathrm{CO}_{2} \text { emissions }\end{array}$} & 44339 & 79678 & - & 39780 & 76509 \\
\hline \multicolumn{2}{|c|}{$\begin{array}{l}\text { Total Economic cost/ Total } \mathrm{CO}_{2} \\
\text { emissions }\end{array}$} & 78557 & 84694 & - & 77645 & 82830 \\
\hline
\end{tabular}

\subsubsection{Optimization of the polygeneration system for a residential building based on $R D$ $244 / 2019$}

Tables 14 and 15 show the optimal design of a polygeneration system for a residential building based on the RD 244/2019. The contracted power for the collective installation varies for each scenario, achieving reductions of up to about $69 \%$ in scenarios 1 and 2, and up to about $58 \%$ in scenario 3 with respect to the reference scenario. The reduction in contracted power is mainly due to the installation of CM and PV panels. Regarding equipment capacity, TSQ capacity is negligible taking into account the size scale. The replacement of the mechanical chiller for a reversible HP enables the GB capacity to be reduced, and the installation of TSR enables the reversible HP capacity to be reduced. In economic terms, from reference scenario to scenario 1 there was a reduction of about $46 \%$ and $16 \%$ in the operational and total annual costs, respectively. From scenario 1 to scenario 2 there was a reduction of about $8 \%$ in the operational cost but it was negligible in the total annual cost. From scenario 2 to scenario 3 there was a reduction of about $37 \%$ and $7 \%$ in the operational and total annual costs, respectively. From the environmental point of view, from reference scenario to scenario 1 there was a reduction of about $13 \%$ and $10 \%$ in the operational and total $\mathrm{CO}_{2}$ emissions respectively. From scenario 1 to 2 there was a reduction about $10 \%$ and $8 \%$ in operational and total $\mathrm{CO}_{2}$ emissions respectively. From scenario 2 to 3 there was a significant reduction of about $35 \%$ and 
$28 \%$ in the operational and total $\mathrm{CO}_{2}$ emissions respectively. This is mainly because in scenarios 1 and 2 the exploited area for PV panels is about 32\% and 41\% respectively, whereas in scenario 3 is about $74 \%$. The available area for installing PV panels is a key factor for the reduction of $\mathrm{CO}_{2}$ emissions. The limit value of $2000 \mathrm{~m}^{2}$ for the available area is an assumption only to evaluate how much PV panels could be installed in the different scenarios.

Table 14. Results of the optimization of the polygeneration system for a residential building by applying RD 244/2019. Reference scenario and scenario 1

\begin{tabular}{|c|c|c|c|c|c|c|}
\hline \multirow{2}{*}{$\begin{array}{c}\text { Technology } \\
j\end{array}$} & \multicolumn{3}{|c|}{ Reference scenario } & \multicolumn{3}{|c|}{ Scenario 1} \\
\hline & Installed Cap & $\mathrm{CIA}_{\mathbf{j}}[€ / \mathbf{y r}]$ & $\begin{array}{c}\mathrm{CO}_{2} \mathrm{fix}_{\mathrm{j}} \\
{\left[\mathrm{kgCO} \mathrm{CO}_{2} \mathrm{eq} / \mathrm{yr}\right]}\end{array}$ & Installed Cap & $\mathbf{C I A}_{\mathbf{j}}[€ / \mathbf{y r}]$ & $\begin{array}{c}\mathrm{CO}_{2} \mathrm{fix}_{\mathbf{j}} \\
{\left[\mathrm{kgCO} \mathrm{C}_{2} \mathrm{eq} / \mathrm{yr}\right]}\end{array}$ \\
\hline Pct $[\mathbf{i} W]$ & $110.851_{1,2} / 20.785_{3}$ & - & - & $34.641_{1,2,3}$ & - & - \\
\hline CM & - & - & - & 17 kWe & 6250 & 111 \\
\hline PV & - & - & - & $256 \mathrm{~m}^{2}$ & 6416 & 2057 \\
\hline HP & $325 \mathrm{kWt}$ & 22747 & 2603 & $254 \mathrm{kWt}$ & 17738 & 2030 \\
\hline GB & $274 \mathrm{kWt}$ & 3824 & 137 & $116 \mathrm{kWt}$ & 1618 & 58 \\
\hline TSR & - & - & - & $118 \mathrm{kWht}$ & 5254 & 668 \\
\hline INV & - & - & - & $48 \mathrm{~kW}$ & 3302 & 914 \\
\hline \multicolumn{2}{|c|}{$\begin{array}{l}\text { Investment annual cost / } \\
\text { Embodied } \mathrm{CO}_{2} \text { emissions }\end{array}$} & 26571 & 2740 & - & 40578 & 5837 \\
\hline & $\begin{array}{c}\text { Consumption } \\
{[\mathrm{kWh} / \mathrm{yr}]}\end{array}$ & $\begin{array}{c}\text { Energy cost } \\
{[€ / \mathrm{yr}]}\end{array}$ & $\begin{array}{l}\mathrm{CO}_{2} \text { emissions } \\
{\left[\mathrm{kgCO}_{2} \mathrm{eq} / \mathrm{yr}\right]}\end{array}$ & $\begin{array}{c}\begin{array}{c}\text { Consumption } \\
{[\mathrm{kWh} / \mathrm{yr}]}\end{array} \\
\end{array}$ & $\begin{array}{c}\text { Energy cost } \\
{[€ / \mathrm{yr}]}\end{array}$ & $\begin{array}{l}\mathrm{CO}_{2} \text { emissions } \\
{\left[\mathrm{kgCO}_{2} \mathrm{eq} / \mathrm{yr}\right]}\end{array}$ \\
\hline $\begin{array}{l}\text { Purchased } \\
\text { Electricity }\end{array}$ & 161495 & 42681 & 33341 & 44151 & 11523 & 9427 \\
\hline Natural gas & 303757 & 18189 & 62088 & 358411 & 21286 & 73259 \\
\hline \multicolumn{2}{|c|}{$\begin{array}{l}\text { Operational Economic cost/ } \\
\text { Operational } \mathrm{CO}_{2} \text { emissions }\end{array}$} & 60869 & 95429 & - & 32809 & 82686 \\
\hline \multicolumn{2}{|c|}{$\begin{array}{l}\text { Total Economic cost/ Total } \mathrm{CO}_{2} \\
\text { emissions }\end{array}$} & 87440 & 98169 & - & 73387 & 88524 \\
\hline
\end{tabular}

Table 15. Results of the optimization of the polygeneration system for a residential building by applying RD 244/2019. Scenarios 2 and 3

\begin{tabular}{|c|c|c|c|c|c|c|}
\hline \multirow[b]{2}{*}{$\begin{array}{c}\text { Technology } \\
j\end{array}$} & \multicolumn{3}{|c|}{ Scenario 2} & \multicolumn{3}{|c|}{ Scenario 3} \\
\hline & Installed Cap & $\mathrm{CIA}_{\mathbf{j}}[€ / \mathrm{yr}]$ & $\begin{array}{c}\mathrm{CO}_{2} \mathrm{fix}_{\mathbf{j}} \\
{\left[\mathrm{kgCO} \mathrm{O}_{2} \mathbf{e q} / \mathrm{yr}\right]}\end{array}$ & Installed Cap & $\mathbf{C I A}_{\mathbf{j}}[€ / \mathbf{y r}]$ & $\begin{array}{c}\mathrm{CO}_{2} \mathrm{fix}_{\mathrm{j}} \\
{\left[\mathrm{kgCO} \mathrm{O}_{2} \mathrm{eq} / \mathrm{yr}\right]}\end{array}$ \\
\hline Pct $_{i}[k W]$ & $34.641_{1,2,3}$ & - & - & $43.648_{1,2,3}$ & - & - \\
\hline $\mathbf{C M}$ & $17 \mathrm{kWe}$ & 6349 & 112 & $7 \mathrm{kWe}$ & 2411 & 43 \\
\hline PV & $327 \mathrm{~m}^{2}$ & 8210 & 2633 & $599 \mathrm{~m}^{2}$ & 15037 & 4822 \\
\hline HP & $279 \mathrm{kWt}$ & 19497 & 2231 & $297 \mathrm{kWt}$ & 20751 & 2375 \\
\hline GB & $112 \mathrm{kWt}$ & 1560 & 56 & $141 \mathrm{kWt}$ & 1970 & 70 \\
\hline TSQ & $3 \mathrm{kWht}$ & 115 & 9 & $0.0 \mathrm{kWht}$ & 0 & 0 \\
\hline TSR & $60 \mathrm{kWht}$ & 2942 & 374 & $27 \mathrm{kWht}$ & 1292 & 164 \\
\hline INV & $61 \mathrm{~kW}$ & 4225 & 1169 & $112 \mathrm{~kW}$ & 7740 & 2142 \\
\hline \multicolumn{2}{|c|}{$\begin{array}{l}\text { Investment annual cost / } \\
\text { Embodied } \mathrm{CO}_{2} \text { emissions }\end{array}$} & 42897 & 6584 & - & 49201 & 9616 \\
\hline & $\begin{array}{c}\text { Consumption } \\
{[\mathrm{kWh} / \mathrm{yr}]}\end{array}$ & $\begin{array}{c}\text { Energy cost } \\
{[€ / \mathrm{yr}]}\end{array}$ & $\begin{array}{l}\mathrm{CO}_{2} \text { emissions } \\
{\left[\mathrm{kgCO}_{2} \mathrm{eq} / \mathrm{yr}\right]} \\
\end{array}$ & $\begin{array}{c}\text { Consumption } \\
{[\mathrm{kWh} / \mathrm{yr}]}\end{array}$ & $\begin{array}{c}\text { Energy cost } \\
{[€ / \mathrm{yr}]}\end{array}$ & $\begin{array}{l}\mathrm{CO}_{2} \text { emissions } \\
{\left[\mathrm{kgCO}_{2} \mathrm{eq} / \mathrm{yr}\right]}\end{array}$ \\
\hline $\begin{array}{l}\text { Purchased } \\
\text { Electricity }\end{array}$ & 42888 & 11276 & \multirow{2}{*}{6815} & 73650 & 18635 & \multirow{2}{*}{517} \\
\hline $\begin{array}{c}\text { Sold } \\
\text { Electricity }\end{array}$ & 10463 & -878 & & 77127 & -13957 & \\
\hline Natural gas & 333248 & 19860 & 68116 & 237516 & 14434 & 48548 \\
\hline \multicolumn{2}{|c|}{$\begin{array}{l}\text { Operational Economic cost/ } \\
\text { Operational CO2 emissions }\end{array}$} & 30258 & 74931 & - & 19112 & 49065 \\
\hline \multicolumn{2}{|c|}{$\begin{array}{r}\text { Total Economic cost/ Total } \\
\mathrm{CO}_{2} \text { emissions }\end{array}$} & 73155 & 81515 & - & 68312 & 58681 \\
\hline
\end{tabular}




\subsection{Individual and Collective installations comparison}

The total annual cost and $\mathrm{CO}_{2}$ emissions per dwelling were calculated for the case of the residential building consisting of 50 dwellings. These results were compared with individual installations in order to evaluate the advantages and disadvantages of both types of installations from the economic and environmental point of view. It is noteworthy in reference scenario (see tables 16 and 17) that in collective installations the cost per dwelling is lower than in individual installations. The reason is the reduction of natural gas cost when its consumption is increased (See table 7), which is a common feature in most of countries [86].

Table 16 presents the total annual cost and $\mathrm{CO}_{2}$ emission of the optimal design of a polygeneration system for a residential building by applying legal restrictions based on the RD 900/2015. According to these results, the use of collective installations enables the reduction of the total annual cost per dwelling about $22 \%$ with respect to individual installations. However, apart from reference scenario, $\mathrm{CO}_{2}$ emissions per dwelling increase by using collective installations in every scenario, about $70 \%$ in scenario 1 , and about $40 \%$ in scenarios 2 and 3, with respect to the emissions corresponding to the individual installations.

Table 16. Total annual cost and $\mathrm{CO}_{2}$ emissions per dwelling based on RD 900/2015.

\begin{tabular}{|c|c|c|c|c|}
\hline \multirow[b]{2}{*}{ Scenarios } & \multicolumn{2}{|c|}{ Individual Installation } & \multicolumn{2}{|c|}{ Collective installation } \\
\hline & $\begin{array}{c}\text { Total Annual } \\
\text { cost }[€ / y r]\end{array}$ & $\begin{array}{c}\text { Total } \mathrm{CO}_{2} \text { emissions } \\
{\left[\mathrm{kgCO}_{2} \mathrm{eq} / \mathrm{yr}\right]}\end{array}$ & $\begin{array}{c}\text { Total Annual } \\
\text { cost [€/yr] }\end{array}$ & $\begin{array}{c}\text { Total } \mathrm{CO}_{2} \text { emissions } \\
{\left[\mathrm{kgCO}_{2} \mathrm{eq} / \mathrm{yr}\right]}\end{array}$ \\
\hline Reference scenario & 2236 & 1982 & 1749 & 1963 \\
\hline Scenario 1 & 2019 & 998 & 1571 & 1697 \\
\hline Scenario 2 & \multirow{2}{*}{2043} & \multirow{2}{*}{1200} & 1571 & 1694 \\
\hline Scenario 3 & & & 1553 & 1657 \\
\hline
\end{tabular}

Table 17 presents the total annual cost and $\mathrm{CO}_{2}$ emissions of the optimal design of a polygeneration system for a residential building by applying legal restrictions based on the RD 244/2019. The use of collective installations enables the reduction of the total annual cost per dwelling about $27 \%$ in scenarios 1 and 2 and about 32\% in scenario 3 . In contrast, $\mathrm{CO}_{2}$ emissions per dwelling were increased by using collective installations about $77 \%, 68 \%$ and $21 \%$ in scenarios 1,2 and 3 respectively.

Table 17. Total annual cost and $\mathrm{CO}_{2}$ emissions per dwelling based on RD 244/2019.

\begin{tabular}{|c|c|c|c|c|}
\hline \multirow[b]{2}{*}{ Scenarios } & \multicolumn{2}{|c|}{ Individual Installation } & \multicolumn{2}{|c|}{ Collective installation } \\
\hline & $\begin{array}{c}\text { Total Annual } \\
\text { cost }[€ / y r]\end{array}$ & $\begin{array}{c}\text { Total } \mathrm{CO}_{2} \text { emissions } \\
{\left[\mathrm{kgCO}_{2} \mathrm{eq} / \mathrm{yr}\right]}\end{array}$ & $\begin{array}{c}\text { Total Annual } \\
\text { cost }[€ / \mathrm{yr}]\end{array}$ & $\begin{array}{c}\text { Total } \mathrm{CO}_{2} \text { emissions } \\
{\left[\mathrm{kgCO}_{2} \mathrm{eq} / \mathrm{yr}\right]}\end{array}$ \\
\hline Reference scenario & 2236 & 1982 & 1749 & 1963 \\
\hline Scenario 1 & 2019 & 998 & 1468 & 1770 \\
\hline Scenario 2 & 2017 & 973 & 1463 & 1630 \\
\hline Scenario 3 & 2015 & 973 & 1366 & 1174 \\
\hline
\end{tabular}

The obtained results are remarkable taking into account that the $\mathrm{CO}_{2}$ emissions reduction is a very important factor to be considered in the energy policy. Encouraging the collective installations should lead to decrease both the total annual cost and the $\mathrm{CO}_{2}$ emissions per dwelling, but it does not. In the three scenarios, the $\mathrm{CO}_{2}$ emissions per 
dwelling in residential buildings are higher than the obtained from individual installations.

This increase of $\mathrm{CO}_{2}$ emissions per dwelling is partly due to the natural gas consumption of the cogeneration module. In order to evaluate the impact of the cogeneration in the $\mathrm{CO}_{2}$ emissions, the energy system is optimized not allowing the installation of this technology. Figures 5 and 6 present the obtained results for a household (Hh), residential building per dwelling considering cogeneration (RB-CM), and residential building per dwelling without cogeneration (RB-Not CM) for both regulations.

The economic and environmental impact of the optimization of polygeneration system per dwelling based on the RD 900/2015 is shown in the Figure 5. There is a $\mathrm{CO}_{2}$ emissions reduction of about 7-9\% when $\mathrm{CM}$ technology is not part of the optimal configuration with respect to $\mathrm{RB}-\mathrm{CM}$. However, $\mathrm{CO}_{2}$ emissions results in residential building per dwelling remain higher than household results in every scenario.

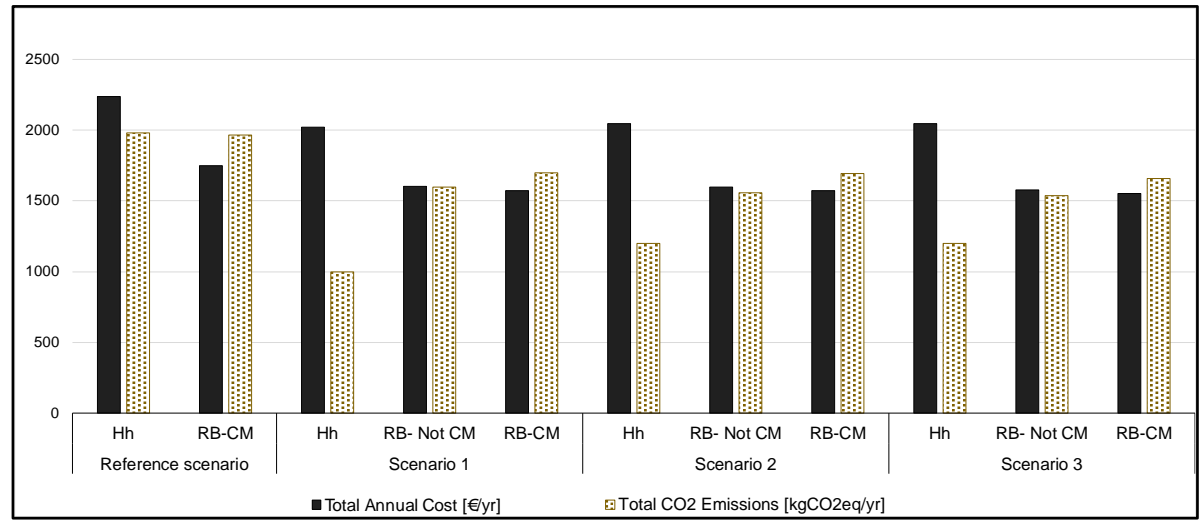

Figure 5. Economic and environmental impact of the optimization of polygeneration system per dwelling based on RD 900/2015

The economic and environmental impact of the optimization of polygeneration system per dwelling based on the RD 244/2019 is shown in the figure 6. There is a $\mathrm{CO}_{2}$ emissions reduction of about 15-20\% when CM technology is not part of the optimal configuration with respect to RB-CM. However, the $\mathrm{CO}_{2}$ emissions results in residential building per dwelling remain higher than household results. Unlike RD 900/2015, the RD 244/2019 does not have restrictions on installed self-consumption system capacity, which allows the installation of as much PV panels as possible in scenario 3, leading to reduce the $\mathrm{CO}_{2}$ emissions significantly. 


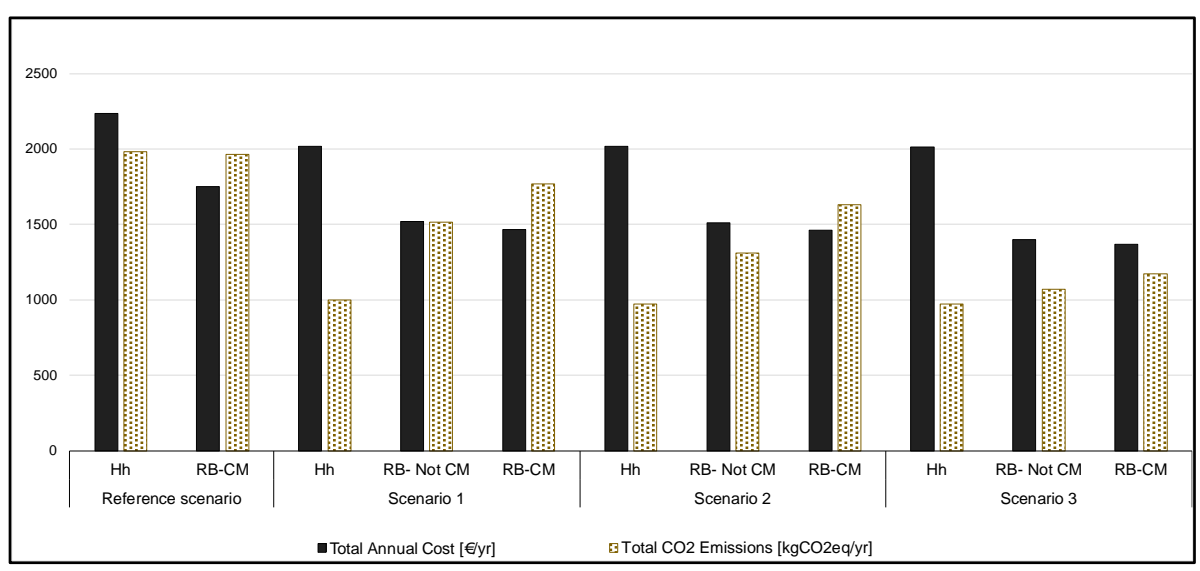

Figure 6. Economic and environmental impact of the optimization of polygeneration system per dwelling based on RD 244/2019

The fact that the $\mathrm{CO}_{2}$ emissions per dwelling in residential buildings remain higher than household is because the natural gas consumption increases significantly whereas purchased electricity decreases in the residential building per dwelling as depicted in the figure 7. This is because under the current natural gas prices structure, the higher the natural gas consumption, the lower the natural gas price. Based on the obtained results, this prices structure should change in order to do not favour a larger consumption of fossil fuels (natural gas), at least for the residential sector (residential buildings-collective installations). In this way, more environmental-friendly technologies based on renewable energies that could be competitive and profitable would not be penalised and higher reductions of $\mathrm{CO}_{2}$ emissions would be achieved. (See table 7).
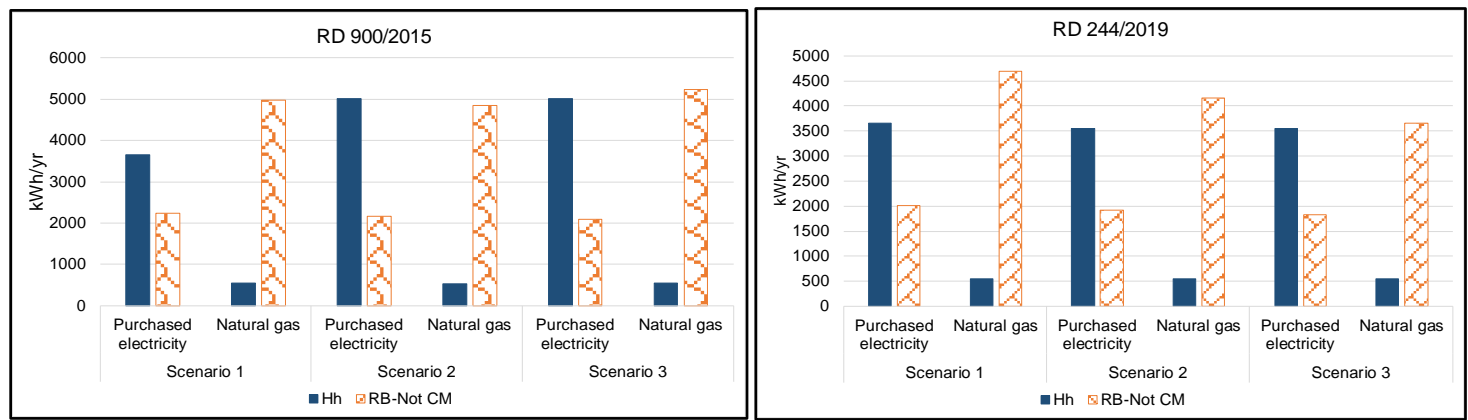

Figure 7. Natural gas consumption and purchased electricity per dwelling based on RD 900/2015 (Left) and RD 244/2019 (Right)

Thus, the natural gas price for residential building (Tariff 3.4) is 26\% lower than for household (Tariff 3.1). On the other hand, the electricity price is higher for residential building than household. Therefore, based on the data shown in the table 18, the increase in the natural gas consumption results in a proportional increase in $\mathrm{CO}_{2}$ emissions. 
Table 18. Electricity and natural gas prices and unit $\mathrm{CO}_{2}$ emissions

\begin{tabular}{|c|c|c|c|c|}
\hline \multicolumn{2}{|c|}{ Fuel } & $\begin{array}{c}\text { Household } \\
\text { [€/kWh] }\end{array}$ & $\begin{array}{c}\text { Dwelling-Building } \\
{[€ / \mathbf{k W h}]}\end{array}$ & $\begin{array}{c}\text { Unit } \mathrm{CO}_{2} \text { emissions } \\
{[\mathrm{kgCO}} \\
2 \mathrm{eq} / \mathrm{kWh}]\end{array}$ \\
\hline \multicolumn{2}{|c|}{ Natural gas } & 0.063125 & 0.046843 & 0.2044 \\
\hline \multirow{3}{*}{ Electricity } & P1 & 0.173941 & $\begin{array}{c}0.189 \\
\sim\end{array}$ & \multirow{3}{*}{$\begin{array}{c}\text { Variable } \\
(0.0633-0.3811) \\
\text { Annual Average } \\
0.208\end{array}$} \\
\hline & P2 & 0.099554 & $\sim 0.169$ & \\
\hline & P3 & 0.076838 & $\sim 0.125$ & \\
\hline
\end{tabular}

\subsection{Comparison of results of the optimization of polygeneration systems under RD 900/2015 and RD 244/2019}

The use of polygeneration systems with respect to conventional systems (reference scenario) provides economic and environmental benefits in all analysed cases. In individual installations (households), economic benefits were about $10 \%$, whereas $\mathrm{CO}_{2}$ emissions reductions of about 50\%, when PV technology was selected, for both regulations. The main reason of this difference in this case was the taxation imposed to self-consumption in RD 900/2015, which represented a barrier to its development. In collective installations (residential buildings), the economic benefits were about $10 \%$ and 20\% based on the application of RD 900/2015 and RD 244/2019 respectively. On the other hand, the $\mathrm{CO}_{2}$ emissions reduction was only about $14 \%$ for both regulations with respect to the reference system, except for the scenario 3 based on RD 244/2019, which enables $\mathrm{CO}_{2}$ emissions reduction about $40 \%$, thanks to the installation of a significant capacity of PV, which is profitable due to the economic revenues obtained with selfproduced electricity sale at $80 \%$ of the retail price.

When comparing collective versus individual installations, it was observed that both regulations enable economic benefits of about $25 \%$ when using collective installations. However, promoting collective installations could lead to an increase of the $\mathrm{CO}_{2}$ emissions up to about $77 \%$ with respect individual installations in some scenarios. Therefore, promoting collective installations does not necessarily lead to accomplish the targets of $\mathrm{CO}_{2}$ emissions reduction, on the contrary, it could lead to increase the environmental impact under the current conditions.

Obtained results presented in this Section 3 are consistent with the work developed by other authors, although a direct comparison is not possible due to the specificity of the work presented in this paper. Thus, Huang et al. [21] designed several hybrid energy systms for grid-connected net zero energy buildings in Hong Kong and concluded that hybrid systems integrating PV and CM where more robust than the other three hybrid energy systems under the same design conditions. Sigarchian et al. [18] optimized a grid connected polygeneration system for a residential complex located in the north of Italy, operating under a net billing scheme, consisting of similar components as considered in this paper (CM, HP, ACH, WT, TSQ, TSR, Bat, etc.) and obtained considerable cost reduction (about 20\%) and $\mathrm{CO}_{2}$ emissions reduction (about 40\%) compared to conventional separate heat and power production. Finally, Pina et al. [22] developed a multiobjective framework for the synthesis of polygeneration systems and applied to a residential multifamily building consisting of 100 dwellings in Spain, and reached also the conclusion of the important role of $\mathrm{HP}$ in the reduction of $\mathrm{CO}_{2}$ emissions, as well as the economic interest of installing $\mathrm{PV}$ at the expense of $\mathrm{CM}$ when additional $\mathrm{CO}_{2}$ 
reduction was required. Moreover, the installation of TSR was also preferred to TSQ. It is also shown in this work the role of the electrical grid and the interest of purchasing and/or selling electricity to it, providing economic benefit as well as reliability and security to the building energy supply.

\section{Conclusions}

Aiming to evaluate the effect of different regulations in the optimal configuration of polygeneration systems in residential sector, the application of two recent regulations in Spain was studied. The study encompasses the individual installations (households) and residential buildings. A comparison between the regulations in economic and environmental terms were carried out.

The obtained results for individual households show that polygeneration systems based on PV are competitive and profitable without subsidies in self-consumption schemes, even in the case of net billing that limits the amount of renewable electricity that can be sold. In these conditions, in which the technology is competitive without subsidies, is not necessary the application of incentives, such as feed-in tariff, that were applied in the past for the promotion and development of promising technologies. Another interesting result is the competitive role of reversible HP in the provision of energy services with a low environmental impact and with a significant reduction of $\mathrm{CO}_{2}$ emissions with respect to the current conventional schemes (reference scenario).

In the case of collective installations (Residential buildings), both regulations lead to significant economic savings: around 10 \% when RD 900/2015 is applied and up to 24\% when RD 244/2019 is applied. In both cases, the optimal configuration includes PV, CM, HP, GB and TSR. The obtained results show that the main drawback of the RD 900/2015 to achieve economic savings, is the installed capacity restriction of the renewable technologies and cogeneration. On the other hand, although there is no limit to the installed capacity of generation equipment according to the RD 244/2019, this regulation stimulate only the electricity sale generated from renewable primary energy, which discourage to some extent the cogeneration technology.

Attending to the comparison of the individual vs collective installations results, the collective ones are more economically profitable than individual installations in the application of both regulations. However, from the environmental point of view, polygeneration systems for collective installations based on both regulations lead to increase $\mathrm{CO}_{2}$ emissions with respect to individual installations. In scenarios 1 and 2, the use of polygeneration systems in the individual installations enabled $\mathrm{CO}_{2}$ emissions reduction about $40-50 \%$ with respect to conventional systems (reference scenario), whereas by using collective installations the reduction of $\mathrm{CO}_{2}$ emissions per dwelling was only about $9-16 \%$. This is because the higher the natural gas consumption, the lower the natural gas price. The idea of promoting collective installations lies in part, in the fact of taking advantage the more efficient energy systems; however, according to the obtained results, if the design of energy systems remains based on minimizing the economic cost, under the current natural gas prices structure, the best solutions from the economic point of view are those with a high natural gas consumption. Therefore, the legal restrictions 
for residential buildings should take into account this fact, in order to avoid the increase of $\mathrm{CO}_{2}$ emissions.

In scenario 3, the increase of the potential revenues from electricity sale from renewable technology lead to higher $\mathrm{CO}_{2}$ emissions reductions in residential buildings. In this sense the obtained results show that, in a horizon to achieve cero $\mathrm{CO}_{2}$ emissions, the Net Metering scheme could be an interesting and profitable alternative to be considered, since it encourages the free exchange of electricity with the electric grid.

In general, by promoting collective installations, the RD 244/2019 encourages the investment in different renewable energy technologies unlike RD 900/2015, which established a specific taxation to self-consumption installations higher than $10 \mathrm{~kW}$, in spite of that they were profitable.

This taxation represented a barrier to competitive distributed generation. However, the current Spanish regulation is not enough to achieve a significant reduction of $\mathrm{CO}_{2}$ emissions with respect to the individual installations. Based on the obtained results, through the optimal configuration of individual installations it is possible to achieve higher $\mathrm{CO}_{2}$ emissions reduction than those obtained by using collective installations. Therefore, more appropriate regulations with a wider perspective leading to further $\mathrm{CO}_{2}$ emissions reduction in collective installations should be evaluated. The obtained results provide conclusions that are also valid for most of European countries, where the natural gas price for household consumers decreases when increasing the level of consumption. A more appropriate pricing of natural gas, in which its cost was not reduced when increasing its consumption, and in which greenhouse-gas emissions were considered, would lead to the design and installation of energy systems for building providing the required energy systems (polygeneration systems) with significant reduction of $\mathrm{CO}_{2}$ emissions at reasonable and even profitable costs.

The Spanish example, that presents some common features with other countries, presented herein, highlights that inappropriate regulations and/or energy pricing may lead to results which may differ from the pursued objective of, for instance, promoting decentralized energy production and/or reduction of $\mathrm{CO}_{2}$ emissions. Therefore, future efforts should be devoted to improve self-consumption regulation, with a broader perspective than the current policy, oriented to a more significant reduction of $\mathrm{CO}_{2}$ emissions at an affordable cost.

\section{Acknowledgment}

This work was developed in the frame of the research project ENE2017-87711-R, partially funded by the Spanish Government (Energy Program), the Government of Aragon (Ref: T55-17R), Spain, and the EU Social Fund (FEDER Program 2014-2020 "Building Europe from Aragon"). Thanks are extended the mobility program for LatinAmericans offered by Unizar-Santander Universities. 


\section{Appendix A. Primary energy savings PES for cogeneration}

Primary energy savings PES are calculated as follows:

$P E S=1-\frac{F_{\text {cogen }}}{\frac{E_{\text {cogen }}}{\operatorname{Ref}_{E}}+\frac{Q_{\operatorname{cogen}}}{\operatorname{Ref}_{Q}}}$

$E_{\text {cogen: }}$ CM Electricity production [kWh/yr].

Fcogen: CM Fuel consumption $[\mathrm{kWh} / \mathrm{yr}]$

Qcogen: CM useful heat production [kWh/yr]

Refq: Reference Efficiency value to produce heat (for domestic hot water) in a conventional system, 0.92 [87].

$R e f_{E}$ : Reference Efficiency value to produce electricity in a conventional system, 0.53 [87].

Moreover, some correction factors must be applied on $\operatorname{Ref}_{E}$ [87], as follows:

- Correction factors relating to the average climatic situation $\left(\mathrm{F}_{\mathrm{cz}}\right)$ : For Zaragoza, average temperature is about $15^{\circ} \mathrm{C}$ [88], therefore, the correction factor is 0 .

- Correction factors for avoided grid losses $\left(\mathrm{F}_{\mathrm{gl}}\right)$ : This study is for low voltage (below $450 \mathrm{~V}$ ). The correction factors to apply are: 0.888 for electricity exported to the grid and 0.851 for electricity consumed on-site, according to the Spanish version of the establishing harmonised efficiency reference values [87].

$\operatorname{Ref}_{E}{ }^{*}=\left(R e f_{E}+F_{C Z}\right) \cdot F_{g l}$

\section{Nomenclature}

Hh: Household

$R B$ : Residential building

Energy demands

Qd: Heating demand

$\mathrm{R}_{\mathrm{d}}$ : Cooling demand

Ed: Electricity demand

Renewable energy production

Epv: Hourly photovoltaic energy production per square meter

Est: Hourly solar thermal energy production per square meter

Ew: Hourly electrical production of a wind turbine

\section{Equipment}

PV: Photovoltaic panels

WT: Wind turbine

ST: Solar thermal collectors 
Inv: Inverter

InvC: Inverter-Charger

GB: Gas boiler

HP: Heat Pump

ACH: Absorption Chiller

TSQ: Thermal energy storage for heating

TSR: Thermal energy storage for cooling

CM: Cogeneration module

Data Cost

CIA: Annual investment cost [€/yr]

Cop: Annual operational cost [€/yr]

$C_{e}$ : Electricity bill cost [€/yr]

$C_{g}$ : Annual cost of fuel consumption [€/yr]

$C_{\text {fix: }}$ Fixed cost bill [€/yr]

$C_{\text {alq: }}$ : Meter equipment rental cost [ $\left.€ / \mathrm{yr}\right]$

CRF: Capital Recovery Factor 0.0802

$\mathrm{Cu}$ : Unit Cost $[€ / *]$

$c p$ : Purchase electricity/natural gas price [€/kWh]

cs: Electricity sale price [€/kWh]

Find: Indirect cost factor

FNPV: Net Present Value factor

$F_{m}$ : Installation and maintenance cost factor

Pctnom: Nominal power from the grid [kW]

Taxe: Electricity tax 0.05113

VAT: 0.21 in Zaragoza, Spain.

Energy flows

Ep: Purchased electricity [kWh]

Es: Sold electricity [kWh]

$F$ : Fuel consumption [kWh]

E: Energy [kWh]

$W$ : Electricity production [kWh]

$Q$ : Heating production [kWh]

$R$ : Cooling production [kWh]

Variables

A: Area $\left[\mathrm{m}^{2}\right]$

Cap: Nominal capacity

$N_{W T}$ : Number of wind turbines

$S$ : Store energy [kWh]

$Y$ : Binary variable

Technical parameters

$\alpha_{w}$ : Electric efficiency engine

$\alpha_{q}$ : Thermal efficiency engine 
COP: Coefficient of performance

EER: Energy Efficiency ratio

$\eta$ : Efficiency

$\lambda$ : Energy losses factor for thermal energy storage

$\eta_{\mathrm{rrt}}$ : Round trip efficiency of the battery

DOD: Maximum deep of discharge of the battery

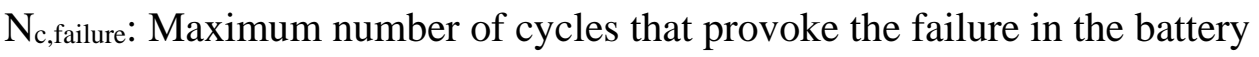

$\alpha_{c}$ : Battery charge ratio [A/Ah]

Sub-indexes e and g indicate electricity and natural gas, respectively

\section{References}

[1] P. Nejat, F. Jomehzadeh, M.M. Taheri, M. Gohari, M.Z. Muhd, A global review of energy consumption, $\mathrm{CO} 2$ emissions and policy in the residential sector (with an overview of the top ten CO2 emitting countries), Renew. Sustain. Energy Rev. 43 (2015) 843-862. doi:10.1016/j.rser.2014.11.066.

[2] V. Masson-Delmotte, P. Zhai, H.-O. Pörtner, D. Roberts, J. Skea, P.R. Shukla, A. Pirani, W. Moufouma-Okia, C. Péan, R. Pidcock, S. Connors, J.B.R. Matthews, Y. Chen, X. Zhou, M.I. Gomis, E. Lonnoy, T. Maycock, M. Tignor, T. Waterfield, IPCC, 2018: Global Warming of $1.5^{\circ}$ C.An IPCC Special Report on the impacts of global warming of $1.5^{\circ} \mathrm{C}$ above pre-industrial levels and related global greenhouse gas emission pathways, in the context of strengthening the global response to the threat of clim, 2018.

https://www.ipcc.ch/site/assets/uploads/sites/2/2019/06/SR15_Full_Report_High _Res.pdf.

[3] E. Abel, Low-energy buildings, Energy Build. 21 (1994) 169-174. doi:10.1016/0378-7788(94)90032-9.

[4] H. Lund, P.A. Østergaard, D. Connolly, B.V. Mathiesen, Smart energy and smart energy systems, Energy. 137 (2017) 556-565.

doi:10.1016/J.ENERGY.2017.05.123.

[5] L.M. López-Ochoa, J. Las-Heras-Casas, L.M. López-González, P. OlasoloAlonso, Environmental and energy impact of the EPBD in residential buildings in hot and temperate Mediterranean zones: The case of Spain, Energy. 161 (2018) 618-634. doi:10.1016/J.ENERGY.2018.07.104.

[6] P. Mancarella, MES (multi-energy systems): An overview of concepts and evaluation models, Energy. 65 (2014) 1-17. doi:10.1016/J.ENERGY.2013.10.041.

[7] E.A. Pina, Thermoeconomic and environmental synthesis and optimization of polygeneration systems supported with renewable energies and thermal energy storage applied to the residential-commercial sector, Universidad de Zaragoza, 2019. http://zaguan.unizar.es/record/87519/files/TESIS-2020-031.pdf.

[8] L.M. Serra, M.-A. Lozano, J. Ramos, A. V. Ensinas, S.A. Nebra, Polygeneration 
and efficient use of natural resources, Energy. 34 (2009) 575-586.

doi:10.1016/J.ENERGY.2008.08.013.

[9] K. Tapia-Ahumada, I.J. Pérez-Arriaga, E.J. Moniz, A methodology for understanding the impacts of large-scale penetration of micro-combined heat and power, Energy Policy. 61 (2013) 496-512. doi:10.1016/J.ENPOL.2013.06.010.

[10] Y. Tan, X. Wang, Y. Zheng, Modeling and daily operation optimization of a distributed energy system considering economic and energy aspects, Int. J. Energy Res. 42 (2018) 3477-3495. doi:10.1002/er.4070.

[11] K. Jana, A. Ray, M.M. Majoumerd, M. Assadi, S. De, Polygeneration as a future sustainable energy solution - A comprehensive review, Appl. Energy. 202 (2017) 88-111. doi:10.1016/J.APENERGY.2017.05.129.

[12] F.A. Al-Sulaiman, F. Hamdullahpur, I. Dincer, Trigeneration: A comprehensive review based on prime movers, Int. J. Energy Res. 35 (2011) 233-258. doi:10.1002/er.1687.

[13] A. Rong, Y. Su, Polygeneration systems in buildings: A survey on optimization approaches, Energy Build. 151 (2017) 439-454.

doi:10.1016/J.ENBUILD.2017.06.077.

[14] A. Kasaeian, E. Bellos, A. Shamaeizadeh, C. Tzivanidis, Solar-driven polygeneration systems: Recent progress and outlook, Appl. Energy. 264 (2020) 114764. doi:10.1016/J.APENERGY.2020.114764.

[15] E. Bellos, S. Pavlovic, V. Stefanovic, C. Tzivanidis, B.B. NakomcicSmaradgakis, Parametric analysis and yearly performance of a trigeneration system driven by solar-dish collectors, Int. J. Energy Res. 43 (2019) 1534-1546. doi:10.1002/er.4380.

[16] E.S. Pinto, L.M. Serra, Multiobjective Synthesis of a Polygeneration System for a Residential Building Integrating Renewable Energy and Electrical and Thermal Energy Storage, in: A. Häberle (Ed.), Proc. ISES EuroSun 2018 Conf. - 12th Int. Conf. Sol. Energy Build. Ind., 2018: pp. 1454-1465.

http://proceedings.ises.org/?conference=eurosun2018.

[17] A. Modi, F. Bühler, J.G. Andreasen, F. Haglind, A review of solar energy based heat and power generation systems, Renew. Sustain. Energy Rev. 67 (2017) 1047-1064. doi:10.1016/J.RSER.2016.09.075.

[18] S. Ghaem Sigarchian, A. Malmquist, V. Martin, The choice of operating strategy for a complex polygeneration system: A case study for a residential building in Italy, Energy Convers. Manag. 163 (2018) 278-291. doi:10.1016/J.ENCONMAN.2018.02.066.

[19] D. Buoro, P. Pinamonti, M. Reini, Optimization of a Distributed Cogeneration System with solar district heating, Appl. Energy. 124 (2014) 298-308. doi:10.1016/J.APENERGY.2014.02.062.

[20] E.S. Pinto, L.M. Serra, A. Lázaro, Economic and environmental assessment of renewable energy and energy storage integration in standalone polygeneration systems for residential buildings, in: Int. Conf. Sol. Heat. Cool. Build. Ind. Santiago Chile, Chile, Novemb. 04-07, 2019. 
[21] Z. Huang, Y. Lu, M. Wei, J. Liu, Performance analysis of optimal designed hybrid energy systems for grid-connected nearly/net zero energy buildings, Energy. 141 (2017) 1795-1809.

doi:https://doi.org/10.1016/j.energy.2017.11.093.

[22] E.A. Pina, M.A. Lozano, L.M. Serra, A multiperiod multiobjective framework for the synthesis of trigeneration systems in tertiary sector buildings, Int. J. Energy Res. (2020) 1140-1166. doi:10.1002/er.5006.

[23] M.A. Lozano, J.C. Ramos, L.M. Serra, Cost optimization of the design of CHCP (combined heat, cooling and power) systems under legal constraints, Energy. 35 (2010) 794-805. doi:10.1016/J.ENERGY.2009.08.022.

[24] R. Dufo-López, J.L. Bernal-Agustín, A comparative assessment of net metering and net billing policies. Study cases for Spain, Energy. 84 (2015) 684-694. doi:10.1016/J.ENERGY.2015.03.031.

[25] IEA, World Energy Outlook 2018, (2018). https://www.iea.org/weo2018/ (accessed September 25, 2019).

[26] IRENA, Innovation landscape brief: Net billing schemes, Abu Dhabi, 2019. https://www.irena.org//media/Files/IRENA/Agency/Publication/2019/Feb/IRENA_Net_billing_2019.pd f?la=en\&hash=DD239111CB0649A9A9018BAE77B9AC06B9EA0D25.

[27] O. Zinaman, A. Aznar, C. Linvill, N. Darghouth, T. Dubbeling, E. Bianco, GridConnected Distributed Generation: Compensation Mechanism Basics, 2017. https://www.nrel.gov/docs/fy18osti/68469.pdf.

[28] G. Masson, J.I. Briano, M.J. Baez, Review and analysis of PV Self-Consumption policies, 2016.

https://nachhaltigwirtschaften.at/resources/iea_pdf/reports/iea_pvps_task1_revie w_and_analysis_of_pv_self_consumption_policies_2016.pdf.

[29] Boletin Oficial del Estado, RD 900/2015, Bol. Of. Del Estado. (2015) 94874 917. https://www.boe.es/boe/dias/2015/10/10/pdfs/BOE-A-2015-10927.pdf (accessed October 15, 2018).

[30] Boletin Oficial del Estado, RD 244/2019, (2019) Pág. 35674-35719. https://www.boe.es/boe/dias/2019/04/06/pdfs/BOE-A-2019-5089.pdf (accessed May 6, 2019).

[31] J. Gong, F. You, Sustainable design and synthesis of energy systems, Curr. Opin. Chem. Eng. 10 (2015) 77-86. doi:10.1016/J.COCHE.2015.09.001.

[32] IDAE, Plan Nacional Integrado de Energía y Clima (PNIEC) 2021-2030, (2019). https://www.idae.es/informacion-y-publicaciones/plan-nacional-integrado-deenergia-y-clima-pniec-2021-2030 (accessed September 9, 2019).

[33] Endesa, Anexo Energético de Precios, (2018). https://www.solucionesintegralesendesa.com/media/wysiwyg/endesa/Condicione s/tarifas_electricidad_y_gas_SI.pdf (accessed January 29, 2019).

[34] IDAE, Escala de calificación energética para edificios de nueva construcción, 2009. http://www.idae.es/uploads/documentos/documentos_CALENER_07_Escala_Ca 
lif_Energetica_A2009_A_5c0316ea.pdf (accessed October 18, 2017).

[35] IDAE, Consumos del Sector Residencial en España - Resumen de Información Básica, 2011.

http://www.idae.es/uploads/documentos/documentos_Documentacion_Basica_R esidencial_Unido_c93da537.pdf (accessed November 5, 2017).

[36] IDAE, Código Técnico de la Edificación-Ahorro de energía, (2017). https://www.codigotecnico.org/index.php/menu-ahorro-energia.html (accessed June 4, 2018).

[37] V. Valor, E., Meneu, V., Caselles, Daily air temperature and electricity load in Spain, J. Appl. Meteorol. 40 (2001) 1413-1421.

[38] Meteotest, Meteonorm Software, (2017). http://www.meteonorm.com/ (accessed November 3, 2017).

[39] J. Ramos, Optimization of the design and operation of cogeneration systems for the residential and commercial sector. Ph. D. Thesis, Universidad de Zaragoza, 2012.

[40] A. Viti, DTIE 1.01 Preparación de agua caliente para usos sanitarios, ATECYR, 1996.

[41] AENOR, Instalaciones solares térmicas para producción de agua caliente sanitaria-UNE 94.002, (2005).

[42] J.M. Marín Giménez, Evaluation of alternatives for the energy supply of a residential building in Zaragoza, Universidad de Zaragoza, 2004.

[43] J.A. Duffie, W.A. Beckman, Solar Engineering of Thermal Processes, 4th ed., John Wiley \& Sons, 2013.

[44] Atersa, Specifications of photovoltaic module A-255P, (2017). http://www.atersa.com/Common/pdf/atersa/manuales-usuario/modulosfotovoltaicos/Ficha_Tecnica_A-255P-A-265P_Ultra.pdf (accessed January 6, 2018).

[45] Salvador Escoda S.A, Tarifa de precios, (2017).

https://www.salvadorescoda.com/tarifas/Energias_Renovables_Tarifa_PVP_Salv adorEscoda.pdf (accessed January 6, 2018).

[46] IDAE, Pliego de Condiciones Técnicas de Instalaciones Conectadas a Red, (2011).

http://www.idae.es/uploads/documentos/documentos_5654_FV_pliego_condicio nes_tecnicas_instalaciones_conectadas_a_red_C20_Julio_2011_3498eaaf.pdf.

[47] Bornay, Wind turbine specifications, (2017).

https://www.bornay.com/es/productos/aerogeneradores/wind-plus (accessed January 6, 2018).

[48] Aeolos, Aeolos Wind Turbine 30kW Specification, (2006).

http://www.verdeplus.gr/files/Aeolos H-30kw Brochure.pdf (accessed May 28, 2019).

[49] J.F. Manwell, J.G. McGowan, A.L. Rogers, Wind Energy Explained, 2nd ed., WILEY, 2009. 
[50] REE, Sistema de información del operador del sistema, (2019). https://www.esios.ree.es/es?locale=es (accessed May 28, 2019).

[51] REE, Demanda y producción en tiempo real, (2019). http://www.ree.es/es/actividades/demanda-y-produccion-en-tiempo-real (accessed May 28, 2019).

[52] L. Kotzur, P. Markewitz, M. Robinius, D. Stolten, Impact of different time series aggregation methods on optimal energy system design, Renew. Energy. 117 (2018) 474-487. doi:10.1016/J.RENENE.2017.10.017.

[53] K. Poncelet, H. H oschle, E. Delarue, A. Virag, W.D’haeseleer, Selecting representative days for capturing the implications of integrating intermittent renewables in generation expansion planning problems, IEEE Trans. POWER Syst. 32 (2017). doi:10.1109/TPWRS.2016.2596803.

[54] T. Schütz, M.H. Schraven, M. Fuchs, P. Remmen, D. Müller, Comparison of clustering algorithms for the selection of typical demand days for energy system synthesis, Renew. Energy. 129 (2018) 570-582.

doi:10.1016/J.RENENE.2018.06.028.

[55] E.S. Pinto, L.M. Serra, A. Lázaro, Evaluation of methods to select representative days for the optimization of polygeneration systems, Renew. Energy. 151 (2020) 488-502. doi:10.1016/J.RENENE.2019.11.048.

[56] F. Domínguez-Muñoz, J.M. Cejudo-López, A. Carrillo-Andrés, M. GallardoSalazar, Selection of typical demand days for CHP optimization, Energy Build. 43 (2011) 3036-3043. doi:10.1016/j.enbuild.2011.07.024.

[57] R. Dufo-López, L.A. Fernández-Jiménez, I.J. Ramírez-Rosado, J.S. Artal-Sevil, J.A. Domínguez-Navarro, J.L. Bernal-Agustín, Daily operation optimisation of hybrid stand-alone system by model predictive control considering ageing model, Energy Convers. Manag. 134 (2017) 167-177. doi:10.1016/j.enconman.2016.12.036.

[58] N. DiOrio, A. Dobos, S. Janzou, A. Nelson, B. Lundstrom, Technoeconomic Modeling of Battery Energy Storage in SAM, NREL Technical Report, 2015. https://www.nrel.gov/docs/fy15osti/64641.pdf.

[59] Homer Energy, HOMER® Pro Version 3.7 User Manual, (2016). https://www.homerenergy.com/pdf/HOMERHelpManual.pdf (accessed October 20, 2017).

[60] CogenGreen, Cogeneration, (2014). http://www.cogengreen.com/en (accessed January 31, 2019).

[61] Yanmar, Combined Heat \& Power, (2017). http://www.yanmares.com/products/mchp/ (accessed January 6, 2018).

[62] EU, Directive 2012/27/EU of the european parliament and the council, (2012). https://eur-lex.europa.eu/legalcontent/EN/TXT/PDF/?uri=CELEX:32012L0027\&from=EN.

[63] Carbon footprint, 2016 Carbon conversion factors, (2016). https://www.carbonfootprint.com/2016_carbon_conversion_factors.html (accessed February 14, 2019). 
[64] R. Fu, D. Feldman, R. Margolis, M. Woodhouse, K. Ardani, U.S. Solar Photovoltaic System Cost Benchmark: Q1 2017, 2017. doi:10.2172/1395932.

[65] R. Frischknecht, R. Itten, F. Wyss, Life Cycle Assessment of Future Photovoltaic Electricity Production from Residential - scale Systems Operated in Europe Life Cycle Assessment of Future Photovoltaic., 2015. doi:10.1016/j.jamda.2016.12.070.

[66] A. Orrell, E. Poehlman, Benchmarking U.S. Small Wind Costs With the Distributed Wind Taxonomy, 2017.

https://wind.pnnl.gov/pdf/Benchmarking_US_Small_Wind_Costs_092817_PNN L.pdf (accessed January 15, 2019).

[67] B. Tremeac, F. Meunier, Life cycle analysis of 4.5 MW and $250 \mathrm{~W}$ wind turbines, Renew. Sustain. Energy Rev. 13 (2009) 2104-2110. doi:10.1016/J.RSER.2009.01.001.

[68] A. Bonou, A. Laurent, S.I. Olsen, Life cycle assessment of onshore and offshore wind energy-from theory to application, Appl. Energy. 180 (2016) 327-337. doi:10.1016/J.APENERGY.2016.07.058.

[69] B. Fleck, M. Huot, Comparative life-cycle assessment of a small wind turbine for residential off-grid use, Renew. Energy. 34 (2009) 2688-2696. doi:10.1016/J.RENENE.2009.06.016.

[70] M. Guadalfajara, Economic and environmental analysis of central solar heating plants with seasonal storage for the residential sector. Ph. D. Thesis, Universidad de Zaragoza, 2016.

[71] K. Darrow, R. Tidball, J. Wang, A. Hampson, Catalog of CHP technologies, 2017. https://www.epa.gov/sites/production/files/2015-

07/documents/catalog_of_chp_technologies.pdf (accessed January 4, 2018).

[72] E.A. Pina, M.A. Lozano, L.M. Serra, A Multicriteria Approach for the Integration of Renewable Energy Technologies and Thermal Energy Storage to Support Building Trigeneration Systems, in: Proc. ISES Sol. World Conf. 2017 IEA SHC Sol. Heat. Cool. Conf. Build. Ind. 2017, 2017: pp. 509-520.

[73] Baxi, Catálogo tarifa, (2020). https://mediacdn.baxi.es//media/themes/baxies/images/products/catalogo/catalogo_baxi_2020.pdf?la=eses $\& v=1 \& d=20200316$ T080711Z\&hash=421C9AACFB3D1BD729B41BC2CEC 4CA49 (accessed March 21, 2020).

[74] Daikin, Tarifa Daikin 2019, (2019). https://gduran.com/tarifas/fontaneria/aireacondicionado-catalogo-precios-fontaneria-DAIKIN.pdf (accessed September 10, 2019).

[75] Enertres, Catálogo tarifa 11E, (2017). https://enertres.com/aerotermia/ (accessed May 2, 2019).

[76] M. Beccali, M. Cellura, S. Longo, D. Mugnier, A Simplified LCA Tool for Solar Heating and Cooling Systems, Energy Procedia. 91 (2016) 317-324. doi:10.1016/J.EGYPRO.2016.06.226.

[77] U.S. Department of Energy, Absorption Chillers for CHP Systems, 2017. https://energy.gov/sites/prod/files/2017/06/f35/CHP-Absorption Chiller- 
compliant.pdf (accessed January 7, 2018).

[78] IRENA, Electricity storage and renewables: Costs and markets to 2030, 2017. doi:ISBN 978-92-9260-038-9 (PDF).

[79] J.F. Peters, M. Baumann, B. Zimmermann, J. Braun, M. Weil, The environmental impact of Li-Ion batteries and the role of key parameters - A review, Renew. Sustain. Energy Rev. 67 (2017) 491-506. doi:10.1016/J.RSER.2016.08.039.

[80] SMA, Specifications SUNNY ISLAND 6.0H / 8.0H, (2013). http://files.sma.de/dl/2485/SI_6H8H-AEN131411W.pdf (accessed March 20, 2020).

[81] Victron, Inversores Multiplus, (2017). https://www.victronenergy.com/inverterschargers/multiplus-12v-24v-48v-800va-3kva (accessed August 28, 2019).

[82] JUDELSA, Energética futura-Tarifa de productos, (2018). https://energeticafutura.com/recursos/documentos/tarifa.pdf (accessed January 6, 2018).

[83] V. Fthenakis, M. Raugei, 7 - Environmental life-cycle assessment of photovoltaic systems, Perform. Photovolt. Syst. (2017) 209-232. doi:10.1016/B978-1-78242-336-2.00007-0.

[84] Endesa, Electricity price for Zaragoza, (2019). https://www.endesaclientes.com/static/iberia/empresas/condiciones/anexo-precioelectricidad-es.pdf (accessed May 29, 2019).

[85] LINDO Systems Inc, Lingo-Optimization Modeling Software for Linear, Nonlinear, and Integer Programming, (2013).

[86] Eurostat, Gas prices for household consumers- bi-annual data (from 2007 onwards), (2020). http://appsso.eurostat.ec.europa.eu/nui/show.do?dataset=nrg_pc_202\&lang=en (accessed March 7, 2020).

[87] EU, Establishing harmonised efficiency reference values for separate production of electricity and heat in application of Directive 2004/8/EC, (2015). https://www.boe.es/doue/2015/333/L00054-00061.pdf.

[88] IDAE, Technical guide to measure and determine useful heat, electricity and primary energy savings on high efficiency, 2008. 